\title{
The Synthesis of Biarylmonophosphonates via Palladium-Catalyzed Phosphonation, Iridium-Catalyzed C-H Borylation, Palladium-Catalyzed Suzuki-Miyaura Cross-Coupling
}

\author{
Simon Doherty ${ }^{1}$ ] $\cdot$ Julian G. Knight ${ }^{1} \cdot{\text { Tina S. T. } \operatorname{Tran}^{1} \cdot \text { Hussam Y. Alharbi }}^{1} \cdot$ Daniel O. Perry $^{1}$
}

Received: 12 January 2021 / Accepted: 25 April 2021 / Published online: 7 May 2021

(c) The Author(s) 2021

\section{Abstract}

The iridium-catalyzed C-H borylation of diethyl phenylphosphonate results in nonselective mono and bisborylation to afford a near statistical mixture of 3-, 3,5- and 4-boryl substituted aryl phosphonates whereas 3-substituted aryl phosphonates undergo highly regioselective $\mathrm{C}-\mathrm{H}$ borylation to afford the corresponding meta-phosphonate substituted arylboronic esters as the sole product; the resulting boronic esters were used as nucleophilic reagents in a subsequent palladium-catalyzed Suzuki-Miyaura cross-coupling to generate a range of biarylmonophosphonates. Gratifyingly, the Suzuki-Miyaura cross-coupling can be conducted without purifying the boronic ester which greatly simplifies the synthetic procedure.

\section{Graphical Abstract}

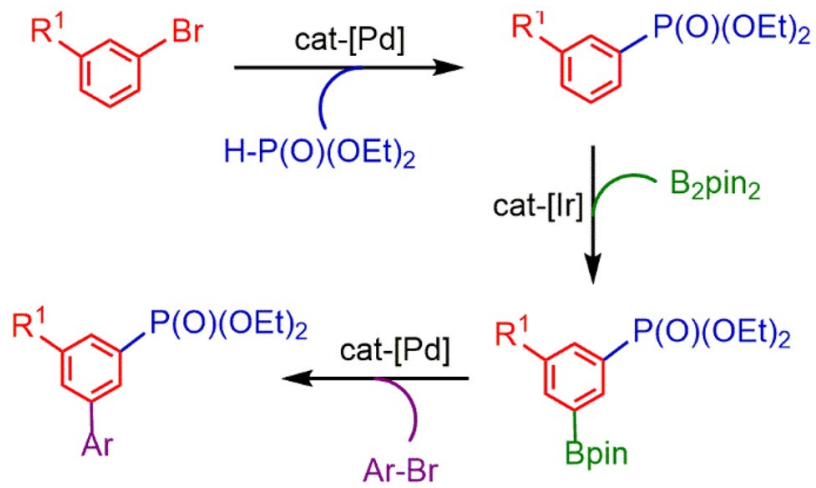

Keywords Iridium-catalyzed C-H borylation $\cdot$ Aryl phosphonates $\cdot$ Meta-selective $\cdot$ Palladium-catalyzed cross-coupling $\cdot$

Biaryl monophosphonates

\section{Introduction}

Arylphosphonates are an important class of molecules as they are key motifs in a host of natural products, bioactive compounds, agrochemicals, and materials as well as intermediates in organic synthesis and precursors to phosphines,

Simon Doherty

simon.doherty@ncl.ac.uk

1 Centre for Catalysis (NUCAT), School of Chemistry,

Newcastle University, Bedson Building, Newcastle

University, Newcastle upon Tyne NE1 7RU, UK which are ubiquitous in organometallic chemistry and catalysis [1-13]. As such the synthesis and elaboration of aryl phosphonates has attracted considerable attention and several strategies based on C-P bond formation have been reported; these include; nickel, copper and palladiumcatalyzed coupling of an aryl halide or pseudo halide with a dialkyl phosphonate [14-26], nickel, copper and palladium-catalyzed oxidative coupling of arylboronic acids or arylsilanes with dialkyl phosphonates [27-33], photoinduced transition metal-free coupling of aryl halides with H-phosphonates [34, 35], nickel-catalyzed decarbonylative 
C-P bond formation [36-38], copper-catalyzed P-arylation between diaryliodonium salts and dialkyl phosphonates [39], palladium-catalyzed phosphorylation of aryl C-H bonds [40-46], dehydrative cross coupling [47], and P-arylation of arynes [48], However, most of these approaches require the use of prefunctionalized substrates and as such are limited in terms of the variety of accessible substrate combinations. Arylphosphonates have also been further elaborated by late-stage modification using either metal catalyzed $\mathrm{C}-\mathrm{H}$ arylation [49-57], where the phosphonate acts as a directing group, or Suzuki Miyaura cross-coupling [58-67]; the latter is an effective strategy for the synthesis of architecturally important achiral and axially chiral biaryl and heterobiarylphosphines, but it requires the use of a pre-functionalized arylphosphonate electrophile as the coupling partner.

As boronic acids and esters are widely used in synthesis [68], we recently initiated a program to develop ortho-phosphonate aryl and naphthylboronic esters as an entirely new class of nucleophilic coupling partner for the synthesis of substituted aryl and heteroaryl phosphonates (Fig. 1a) [69]. While the use of ortho-phosphonate arylboronic esters as the nucleophilic coupling partner complements existing approaches in which the phosphonate is introduced as the electrophile, the synthesis required multiple steps. Clark and Watson have recently reported a markedly more efficient and general method for the synthesis of $o$-boryl arylphosphonates via regioselective $\mathrm{C}-\mathrm{H}$ borylation using a phosphonate as the directing group (Fig. 1b) [70]. This strategy is elegant and highly effective as the starting materials are readily accessible and the catalyst commercially available and it exhibits broad functional group tolerance and is highly flexible in terms of the substitution pattern; moreover, the resulting boronic esters can be converted into a range of

$$
\text { Previous Work }
$$
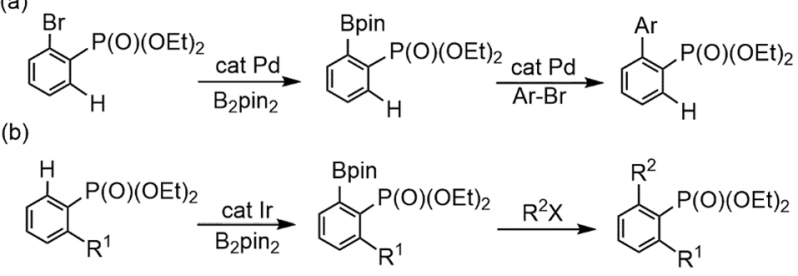

This Work

(c)

$$
\underbrace{\mathrm{P}(\mathrm{O})(\mathrm{OEt})_{2}}_{\mathrm{H}}
$$

Fig. 1 Synthesis of phosphonate-substituted arylboronic esters via a multistep borylation of 2-bromo-substituted aryl phosphonate, b iridium-catalyzed phosphonate-directed ortho $\mathrm{C}-\mathrm{H}$ borylation and c sterically controlled iridium-catalyzed regioselective $\mathrm{C}-\mathrm{H}$ borylation of meta-substituted aryl phosphonates products using conventional organic methods. Even though the use of phosphines as directing groups for ortho-selective $\mathrm{C}-\mathrm{H}$ borylation has previously been reported, the substrate scope is more limited than that accessible using arylphosphonate-directed ortho C-H borylation [71-76].

As part of our ongoing program to develop new crosscoupling partners for the synthesis of biaryl-based motifs we have also been exploring the $\mathrm{C}-\mathrm{H}$ borylation of aryl phosphonates to prepare phosphonate-substituted arylboronic esters as this would avoid the need to prefunctionalise the aryl phosphonate (Fig. 1c). In this regard, the site selectivity of iridium-catalyzed C-H borylation is controlled predominantly by steric factors [77-79], which has been exploited to develop the regioselective meta-directed C-H borylation of 1,3-disubstituted arenes to prepare the corresponding 3,5-disubstituted boronic esters; this is now a powerful protocol that has been widely applied in synthesis to access a host of meta-substituted products including phenols [80], arylamine boronate esters [81], arylamines and ethers [82], arylboronic acids, and trifluoroborates [83], disubstituted bromoarenes [84], aryl nitriles [85], alkylarenes [86], pentafluorosulfanyl-substituted potassium aryltrifluoroborates [87], nitrated arenes [88], difluoromethylated arenes [89], trifluoromethylarenes $[90,91]$ and borylated aryl alkynes [92]. Recently though, alternative approaches have been developed in which meta selective $\mathrm{C}-\mathrm{H}$ borylation has been directed either by noncovalent secondary interactions between a modified bipyridine and the substate by orientating the iridium towards the metal $\mathrm{C}-\mathrm{H}$ bond [93, 94], ion pairing between a cationic substrate and an anionic bipyridine [95], a combination of ligand-substate electrostatic interactions and secondary B-N interactions [96] or Lewis acid-base directed borylation with a bifunctional catalyst [97], however, each of these approaches requires the synthesis of rather elaborate ligands. Since the use of steric factors has proven to be a highly reliable strategy for controlling the regioselectivity of $\mathrm{C}-\mathrm{H}$ borylation, we targeted the iridiumcatalyzed $\mathrm{C}-\mathrm{H}$ borylation of 3-substituted aryl phosphonates to explore whether this protocol would facilitate access to the corresponding phosphonate-substituted arylboronic esters. To this end, the recent report of facile highly selective and divergent acyl and aryl cross-coupling of amides via an iridium-catalyzed $\mathrm{C}-\mathrm{H}$ borylation/ $\mathrm{N}-\mathrm{C}(\mathrm{O})$ activation sequence to prepare biarylketones and biaryls [98] as well as Clarks aryl phosphonate-directed ortho $\mathrm{C}-\mathrm{H}$ borylation [70] have prompted us to disclose the results of our preliminary study on the borylation of aryl phosphonates. Herein, we report that the iridium-catalyzed borylation of diethyl phenylphosphonate results in nonselective mono and bisborylation to afford a mixture of 3-, 3,5- and 4-boryl substituted aryl phosphonates while 3 -substituted aryl phosphonates undergo highly regioselective $\mathrm{C}-\mathrm{H}$ borylation to afford the corresponding meta-phosphonate substituted arylboronic 
esters as the sole product; the resulting boronic esters were also used as the nucleophilic partner in a subsequent palladium-catalyzed Suzuki-Miyaura cross-coupling to generate a diverse range of biaryl monophosphonates.

\section{Results and Discussion}

This project was initiated to explore whether aryl phosphonates would undergo selective $\mathrm{C}-\mathrm{H}$ borylation to afford the corresponding aryl phosphonate-based boronate esters directly in a single step as this would avoid the palladiumcatalyzed borylation of bromo-substituted aryl phosphonates. The recent development of a highly efficient and versatile preparation of $o$-phosphonate arylboronic esters via C-H borylation by Clark [70] encouraged us to report details of our preliminary proof of principle studies in this area. The aryl phosphonates required for this investigation were prepared in high yield via palladium-catalyzed C-P crosscoupling between methyl 3-bromobenzoate (1a), 3-bromotoluene (1b), or 3-bromo-1-trifluoromethylbenzene (1c) and diethyl phosphonate, by adapting previously reported procedures (Scheme 1) [26].

\subsection{Iridium-Catalyzed Borylation of Diethyl Phe- nylphosphonate}

As $\mathrm{C}-\mathrm{H}$ borylation is now well-developed and a powerful tool in synthesis $[99,100]$, preliminary catalytic reactions were conducted using previous literature protocols as a lead [101]. Prior to exploring the C-H borylation of 2a-c, an initial investigation was conducted using diethyl phenylphosphonate $\mathbf{3}$ as the benchmark substrate to determine the selectivity, undertake optimization studies and establish protocols for analysis. Preliminary reactions were conducted in hexane at room temperature using $5 \mathrm{~mol} \%$ catalyst generated from (1,5-cyclooctadiene)(methoxy)iridium(I) dimer and 3,4,7,8-tetramethyl-1,10-phenanthroline (tmphen) as the ligand of choice (Table 1, Entry 1), as it has been widely employed for the non-directed iridium-catalyzed C-H borylation of aryl, heteroaryl and alkyl C-H bonds because it is

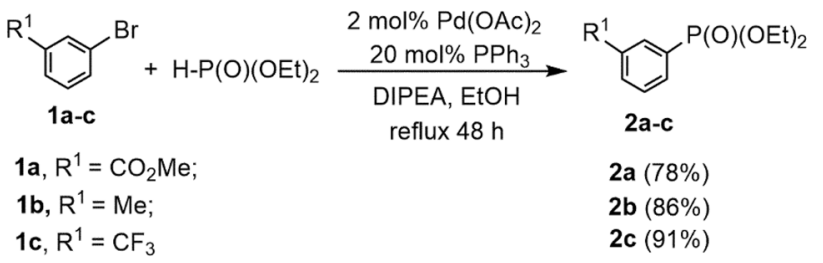

Scheme 1 Synthesis of metal-substituted arylphosphonates 2a-c via palladium-catalyzed C-P cross-coupling between aryl bromides 1a-c and diethyl phosphonate electron rich and its complexes catalyze $\mathrm{C}-\mathrm{H}$ functionalization much more readily than their less electron-rich counterparts [102-105]. Under these conditions, a conversion of $97 \%$ was obtained after $24 \mathrm{~h}$ to afford meta-substituted $\mathbf{4 a}$ as the major product (40\%) together with its 3,5-diboryl substituted counterpart $\mathbf{4 b}(22 \%)$ as well as para-substituted $\mathbf{4 c}$ (35\%) (Table 1 entry 1). To this end, $[\operatorname{Ir}(\mathrm{COD})(\mathrm{OMe})]_{2}$ has been reported to generate the most active bipyridine-based catalysts and the room temperature borylation of arenes with these systems is now common place [77, 78]. Gratifyingly, near quantitative conversions could be obtained after only $1 \mathrm{~h}$ by increasing the reaction temperature to $50{ }^{\circ} \mathrm{C}$; under these conditions the distribution of regioisomers was similar to that obtained at room temperature (Table 1, Entry 2). A survey of catalyst efficacy as a function of solvent for reactions conducted for $1 \mathrm{~h}$ at $50{ }^{\circ} \mathrm{C}$ (Table 1, Entries 2-6) revealed that high conversions were obtained in hexane (94\%), methylcyclohexane (91\%), dioxane (88\%) and THF (70\%) whereas a markedly lower conversion was obtained in dimethyl formamide (3\%). As the highest yields were obtained in hexane, all further studies to identify optimum conditions were conducted in hexane. A reduction in the catalyst loading to $2.5 \mathrm{~mol} \%$ resulted in a markedly lower conversion of $71 \%$ but with a similar distribution of products, under otherwise identical conditions, whereas an increase to $10 \mathrm{~mol} \%$ reached $96 \%$ conversion after only $30 \mathrm{~min}$ (Table 1 , Entries 7-8).

Although $[\operatorname{Ir}(\mathrm{COD})(\mathrm{OMe})]_{2}$ is the most widely used source of iridium for $\mathrm{C}-\mathrm{H}$ borylations, reports of efficient catalysis with alternative iridium precursors prompted us to explore the efficacy of systems generated from $[\operatorname{Ir}(\mathrm{COD})$ (acac)], $[\operatorname{Ir}(\mathrm{COD}) \mathrm{Cl}]_{2}$ or $\left[\operatorname{Ir}(\mathrm{COD})_{2}\right] \mathrm{BF}_{4}$ and tmphen. A screen of each catalyst for the $\mathrm{B}_{2} \mathrm{pin}_{2}$ based borylation of diethyl phenylphosphonate 3 in hexane at $50{ }^{\circ} \mathrm{C}$ for $1 \mathrm{~h}$ revealed that the use of $[\operatorname{Ir}(\mathrm{COD})(\mathrm{acac})]$ and $\left[\operatorname{Ir}(\mathrm{COD})_{2}\right]$ $\mathrm{BF}_{4}$ gave $93 \%$ and $77 \%$ conversion, respectively, while catalyst generated from $[\operatorname{Ir}(\mathrm{COD}) \mathrm{Cl}]_{2}$ only reached $7 \%$ conversion in the same time, although raising the reaction temperature to $70{ }^{\circ} \mathrm{C}$ resulted in a significant improvement in conversion to $51 \%$ after $1 \mathrm{~h}$ (Table 1, Entries 9-11); for each system examined the selectivity profile was similar to that obtained with $[\operatorname{Ir}(\mathrm{COD})(\mathrm{OMe})]_{2}$. Finally, as high conversions have also been obtained for the borylation of benzene using catalysts generated from $[\operatorname{Ir}(\mathrm{COD})(\mathrm{OMe})]_{2}$ and 4,4'-di-tert-butyl-2,2'-bipyridine (dtbpy), 4,4'-dimethyl-2,2'-bipyridine (4,4'- $\mathrm{Me}_{2}$ bpy) or 4,4'-dimethoxy-2,2'bipyridine $\left[4,4\right.$ '- $(\mathrm{OMe})_{2}$ bpy] a brief survey of the influence of these ligands on conversion and selectivity was also undertaken, details of which are summarized in Table 1 (Entries 12-17). There was no significant difference between the efficiency of catalysts generated from either $[\operatorname{Ir}(\mathrm{COD})$ $(\mathrm{OMe})]_{2}$, or $[\operatorname{Ir}(\mathrm{COD})(\mathrm{acac})]$ with each of the 4,4'-disubstituted 2,2'-bipyridines for a series of reactions conducted at 
Table 1 Iridium-catalyzed borylation of diethyl phenylphosphonate $\mathbf{3}$ as a function of solvent, ligand, temperature and boron source

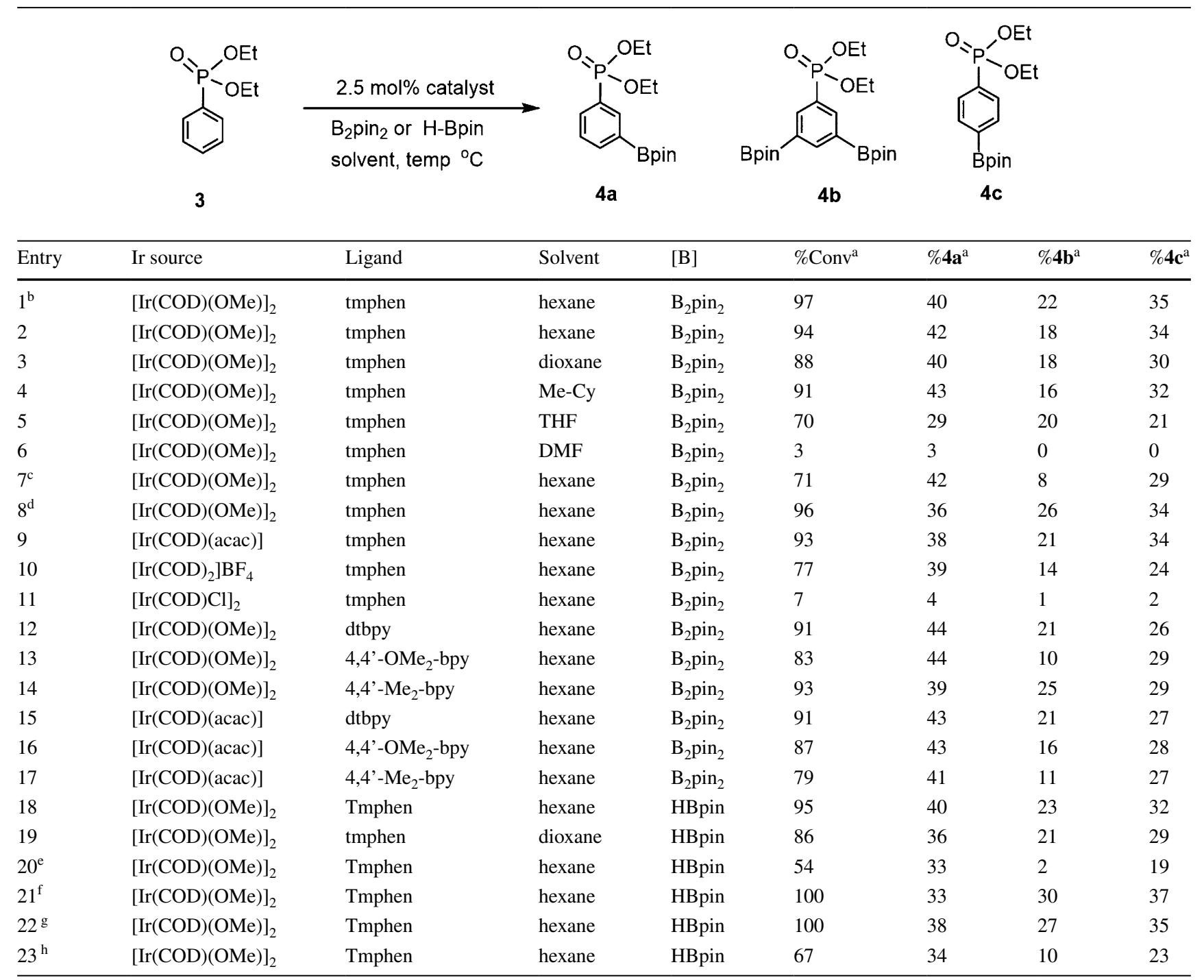

Reaction conditions: $0.37 \mathrm{mmol}$ of $\mathbf{3}, 0.28 \mathrm{mmol} \mathrm{B}_{2} \operatorname{pin}_{2}$ or $0.74 \mathrm{mmol} \mathrm{HBpin,} 2.5 \mathrm{~mol} \%$ [ $\left.\operatorname{Ir}(\mathrm{COD})(\mathrm{OMe})\right]_{2}, 5 \mathrm{~mol} \%$ ligand, $4 \mathrm{~mL}$ solvent, $50{ }^{\circ} \mathrm{C}$, $1 \mathrm{~h}$

${ }^{a}$ Yields determined by ${ }^{31} \mathrm{P}$ NMR spectroscopy. Average of at least three runs

${ }^{\mathrm{b}}$ Reaction conducted at room temperature over $24 \mathrm{~h}$

${ }^{\mathrm{c}}$ Reaction conducted with $1.25 \mathrm{~mol} \%[\operatorname{Ir}(\mathrm{COD})(\mathrm{OMe})]_{2}$ and $2.5 \mathrm{~mol} \%$ ligand under identical conditions

${ }^{\mathrm{d}}$ Reaction conducted with $5 \mathrm{~mol} \%$ [ $\left.\operatorname{Ir}(\mathrm{COD})(\mathrm{OMe})\right]_{2}$ and $10 \mathrm{~mol} \%$ ligand for $30 \mathrm{~min}$ under otherwise identical conditions

${ }^{\mathrm{e}}$ Reaction run with $0.37 \mathrm{mmol} \mathrm{H}-\mathrm{Bpin}$

${ }^{\mathrm{f}}$ Reaction run with $1.1 \mathrm{mmol} \mathrm{H}-\mathrm{Bpin}$

${ }^{\mathrm{g}}$ Reaction run with $1.85 \mathrm{mmol} \mathrm{H}$-Bpin

${ }^{\mathrm{h}} 0.74 \mathrm{mmol}$ of HBpin added after the tmphen

$50{ }^{\circ} \mathrm{C}$ for $1 \mathrm{~h}$. There have been reports of dramatic improvements in reactivity for the iridium-catalyzed $\mathrm{C}-\mathrm{H}$ borylation of phosphines by exchanging the source of boron from bis(pinacolato)diboron $\left(\mathrm{B}_{2} \mathrm{pin}_{2}\right)$ to pinacolborane (HBpin) [75], with the latter proving to be the reagent of choice to obtain high conversions. Under the optimum conditions identified above, the conversions of $95 \%$ and $86 \%$ obtained in hexane and dioxane, respectively with 2 equivalents of $\mathrm{H}$-Bpin after $1 \mathrm{~h}$ at $50{ }^{\circ} \mathrm{C}$ and the corresponding selectivity profile for 4a-c matched those obtained with $\mathrm{B}_{2}$ pin $_{2}$ (Table 1, Entries 18-19). Variation of the HBpin:substrate ratio revealed that conversions dropped quite dramatically as the ratio was reduced to 1 (Table 1, Entry 20) while an increase in this ratio to 3 or 5 resulted in complete conversion but 
with significantly more bisborylation at the two meta positions such that $\mathbf{4 b}$ was obtained as the major product from the reaction with 5 equivalents of HBpin (Table 1, Entries 21-22). Moreover, the performance of catalyst generated from $[\operatorname{Ir}(\mathrm{COD})(\mathrm{OMe})]_{2}$ and tmphen was also shown to be affected by the order of addition of the HBpin and ligand, with systems generated by addition of HBpin before the ligand providing the highest conversions (Table entries 2 and 23) whereas those generated by addition of the ligand before the borane gave a slightly lower conversion, consistent with previous reports [101].

Interested in exploring and comparing the progress of the reaction with $\mathrm{B}_{2}$ pin $_{2}$ and HBpin further, the variation of conversion and composition as a function of time at $50{ }^{\circ} \mathrm{C}$

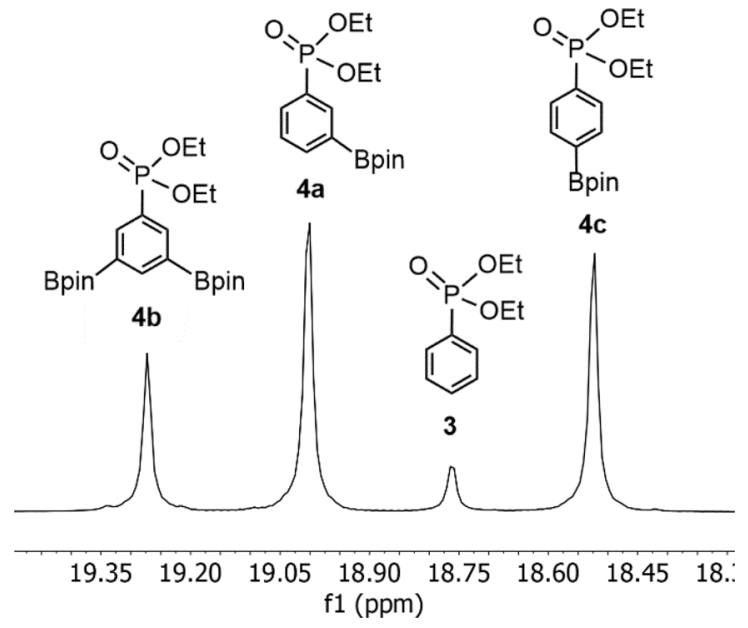

Fig. $2{ }^{31} \mathrm{P}$ NMR spectrum of a reaction mixture from the [ $\operatorname{Ir}(\mathrm{COD})$ $(\mathrm{OMe})]_{2} /$ tmphen catalyzed borylation of diethyl phenylphosphonate (3) after $1 \mathrm{~h}$ at $50{ }^{\circ} \mathrm{C}$ in hexane showing each of the products together with unreacted $\mathbf{3}$ as four distinct well-separated resonances

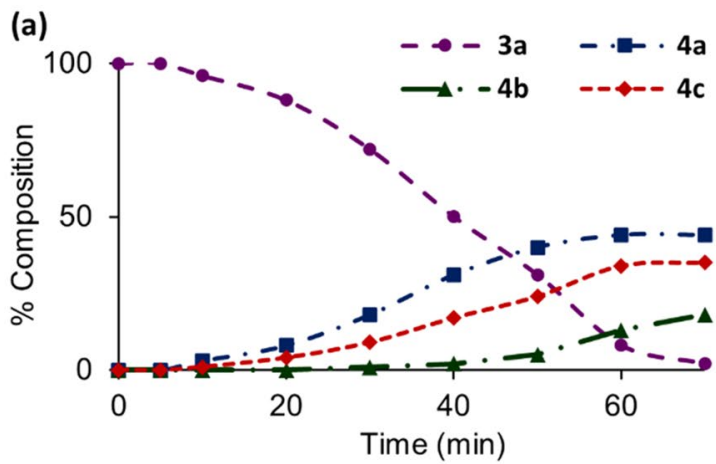

Fig. 3 a Reaction profile as a function of time for the iridium-catalyzed borylation of diethyl phenylphosphonate in hexane at $50{ }^{\circ} \mathrm{C}$ using $2.5 \mathrm{~mol} \%[\operatorname{Ir}(\mathrm{COD})(\mathrm{OMe})]_{2} / 5 \mathrm{~mol} \%$ tmphen and a two mole equivalents of $\mathrm{B}_{2}$ (pin) $)_{2}$ showing non-selective formation of $\mathbf{4 a}, \mathbf{4 b}$ in hexane was monitored and products identified and quantified using ${ }^{31} \mathrm{P}$ NMR spectroscopy, as the products and starting material appeared as distinct well-separated resonances (Fig. 2), the results of this study are presented graphically in Figs. 3a and 3b, respectively. The resulting compositiontime profile obtained for $\mathrm{B}_{2} \mathrm{pin}_{2}$ using $2.5 \mathrm{~mol} \%$ [ $\operatorname{Ir}(\mathrm{COD})$ $(\mathrm{OMe})]_{2}$ and $5 \mathrm{~mol} \%$ tmphen shows an initial induction period followed by gradual consumption of diethyl phenylphosphonate with concomitant formation of $\mathbf{4 a}$ together with $\mathbf{4 c}$ while $\mathbf{4 b}$ begins to form at longer reaction times (Fig. 3a). This profile is consistent with non-selective $\mathrm{C}-\mathrm{H}$ borylation as the ratio of $\mathbf{4 a}+\mathbf{4 b}$ to $\mathbf{4 c}$ is approximately two throughout the reaction, as expected for a near statistical mixture resulting from nonselective reaction at the meta and para positions [77]. For comparison, the corresponding composition-time profile with HBpin (Fig. 3b) shows faster consumption of diethyl phenylphosphonate in the early stages of the reaction to afford $\mathbf{4 a}$ and $\mathbf{4 c}$ and a minor amount of $\mathbf{4 b}$; however, longer reaction times $(<60 \mathrm{~min})$ resulted in a selectivity profile similar to that obtained with $\mathrm{B}_{2} \mathrm{pin}_{2}$. In contrast to the induction period for the $\mathrm{B}_{2} \mathrm{pin}_{2}$ based borylation shown in Fig. 3a, there is no induction with HBpin; such an induction period with $\mathrm{B}_{2} \mathrm{pin}_{2}$ has been attributed to reduction of the 1,5-cyclooctadiene to afford the active trisboryl-tmphen catalyst and this reduction may well be markedly more facile in the presence of HBpin [111]. Indeed, the induction period associated with $\mathrm{B}_{2} \mathrm{pin}_{2}$ based borylations catalyzed by $[\operatorname{Ir}(\mathrm{COD}) \mathrm{Cl}]_{2} / \mathrm{dtbpy}$ can be eliminated by addition of a catalytic amount of HBpin to the reaction mixture [111]. In addition, a high throughput optimization of iridium-catalyzed $\mathrm{C}-\mathrm{H}$ borylation demonstrated that borylations with HBpin rival those with $\mathrm{B}_{2} \mathrm{pin}_{2}$ provided the HBpin is added before the ligand; as the order of addition of HBpin and ligand have been shown to have a dramatic effect on catalyst performance [101].

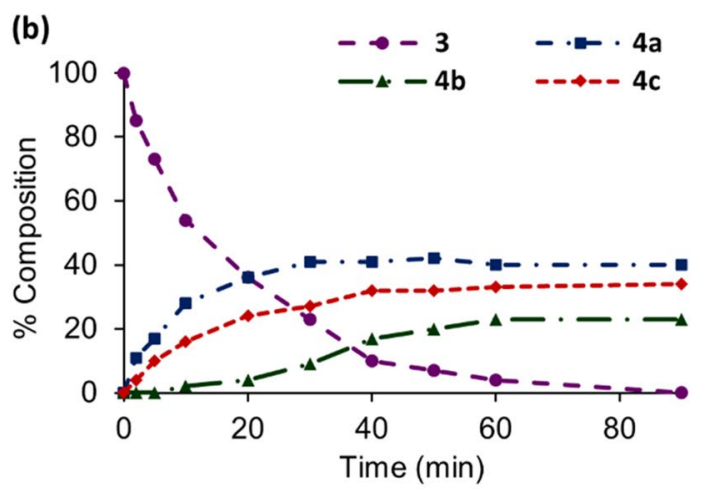

and $\mathbf{4 c}$ and $\mathbf{b}$ two mole equivalents of HBpin showing rapid consumption of diethyl phenylphosphonate with concomitant formation of $\mathbf{4 a}$, $\mathbf{4 b}$ and $\mathbf{4 c}$ and ultimately borylation of $\mathbf{4 a}$ to afford $\mathbf{4 b}$ together with $4 c$ 
In contrast to the mild conditions and short reaction times $\left(50{ }^{\circ} \mathrm{C}, 1 \mathrm{~h}\right)$ required to achieve complete conversion of the diethyl phenylphosphonate using $2.5 \mathrm{~mol} \%$ [ $\operatorname{Ir}(\mathrm{COD})$ $(\mathrm{OMe})]_{2} / \mathrm{tmphen}$, albeit to afford a nonselective mixture of meta and para regioisomers, the $[\operatorname{Ir}(\mathrm{COD})(\mathrm{OMe})]_{2} /[\mathrm{P}[3,5-$ $\left.\left(\mathrm{CF}_{3}\right)_{2} \mathrm{C}_{6} \mathrm{H}_{3}\right]_{3}$ catalyzed arylphosphonate-directed ortho $\mathrm{C}-\mathrm{H}$ borylation of diethyl phenylphosphonate was conducted at $120{ }^{\circ} \mathrm{C}$ for $24 \mathrm{~h}$ and gave a conversion of only $31 \%$; this increased to $42 \%$ with the use of $[\operatorname{Ir}(\mathrm{COD})(\mathrm{acac})]$ as the source of iridium [70]. Such disparate activity between catalysts based on a bipyridine and a diphosphine has previously been highlighted and attributed to the basicity of the phosphine as catalysts with electron-rich phosphines exhibit low activity whereas those with electron-poor phosphines display moderate activity [106-109]. Interestingly, the C-H borylation of diethyl $o$-tolylphosphonate at $100{ }^{\circ} \mathrm{C}$ for $24 \mathrm{~h}$ using catalyst generated from $[\operatorname{Ir}(\mathrm{COD})(\mathrm{acac})]$ and either tmphen or 4,4'-di-tert-butyl-2,2'-bipyridine (dtbpy) resulted in selective borylation meta to the phosphonate to afford the corresponding boronic ester in $38 \%$ and $41 \%$ yield, respectively; of course, the severe conditions employed for this reaction raises the question of whether the presence of the 2-methyl substituent necessitated this high temperature or might the reaction have occurred under the milder conditions described here? The ability of phosphonate to act as a directing group for iridium-catalyzed $\mathrm{C}-\mathrm{H}$ borylation clearly depends on the catalyst formulation as this study has shown that $[\operatorname{Ir}(\mathrm{COD})(\mathrm{acac})] / \mathrm{tmphen}$ is nonselective and affords a statistical mixture of meta- and para-phosphonate phenylboronic esters while $[\operatorname{Ir}(\mathrm{COD})(\mathrm{acac})] /\left[\mathrm{P}\left[3,5-\left(\mathrm{CF}_{3}\right)_{2}-\mathrm{C}_{6} \mathrm{H}_{3}\right]_{3}\right.$ is selective for ortho-borylation, albeit it under markedly different conditions. We speculate that the active 16e iridiumtrisboryl species $\left[\operatorname{Ir}(\mathrm{Bpin})_{3}(\mathrm{tmphen})\right]$ would not be able to coordinate the phosphonate during the $\mathrm{C}-\mathrm{H}$ bond activating oxidative addition/ $\sigma$-bond metathesis step whereas the corresponding $14 \mathrm{e}$ monophosphine-coordinated species would have the capacity to expand its coordination sphere to coordinate the phosphonate and thereby direct the $\mathrm{C}-\mathrm{H}$ activation.

\subsection{Iridium-Catalyzed Borylation of 3-Substituted Phosphonates}

Having established that the borylation of diethyl phenylphosphonate using iridium catalysts supported by bipyridine ligands was non-selective, 3 -substituted phosphonates were identified as the substrates of choice for further studies, reasoning that $\mathrm{C}-\mathrm{H}$ borylation of these substrates would be under steric control and, as such, would occur with high regioselectivity for meta-substitution [99, 100, 110]. Following the optimum conditions identified above for diethyl phenylphosphonate, a series of borylations were conducted with $\mathrm{B}_{2} \mathrm{pin}_{2}$ and aryl phosphonates $\mathbf{2 a - c}$ in hexane at $50{ }^{\circ} \mathrm{C}$ using $5 \mathrm{~mol} \%$ catalyst generated from (1,5-cyclooctadiene) (methoxy)iridium(I) dimer and tmphen in order to identify a suitable reaction time; however, only low yields were obtained at this temperature even after extending the reaction time to $20 \mathrm{~h}$. Gratifyingly, when the reaction temperature was raised to $70{ }^{\circ} \mathrm{C}$, high conversions were obtained and the optimum reaction time was determined by monitoring the variation in conversion and composition as a function of time for the borylation of 2a-c using a combination of ${ }^{1} \mathrm{H}$ and ${ }^{31} \mathrm{P}$ NMR spectroscopy; under these conditions $18 \mathrm{~h}$ was required to reach complete conversion for each substrate to afford the corresponding meta-phosphonate arylboronic esters 5a-c as the sole regioisomer (Table 2) as shorter reaction times resulted in a mixture of $\mathbf{2 a - c}$ and $\mathbf{5 a - c}$. Under these conditions, 5a-c were obtained in high purity after filtration through a short silica plug and did not require further purification prior to modification by Suzuki-Miyaura

Table 2 Iridium-catalyzed borylation of diethyl arylphosphonates $\mathbf{2 a - c}$ as a function of solvent

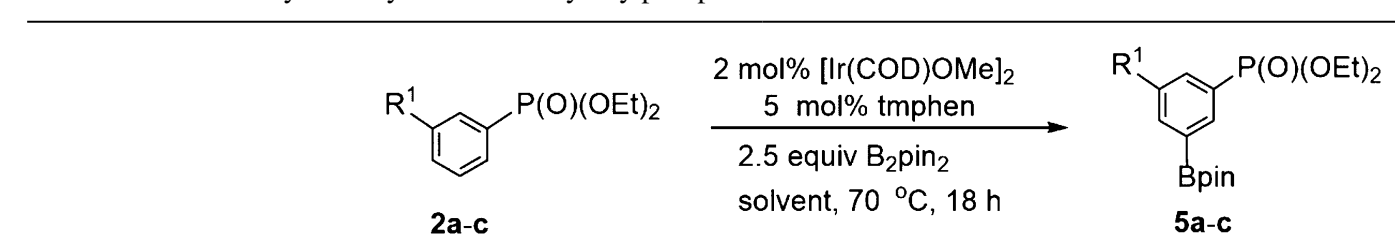
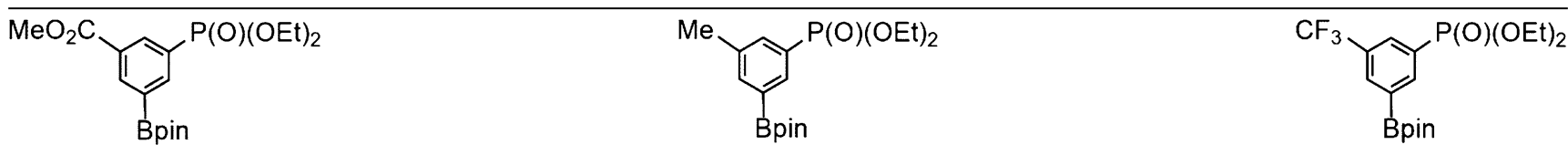

Hexane $^{\text {a }}$ 5a, $100 \%$

$\mathbf{5 b}, 78 \%$
$\mathbf{5 b}, 31 \%$

5c, $88 \%$

$\mathrm{THF}^{\mathrm{a}} \mathbf{5} \mathbf{a}, \mathbf{9 7 \%}$

5c, $85 \%$

Reaction conditions: $0.37 \mathrm{mmol}$ of $\mathbf{2 a - c}, 0.28 \mathrm{mmol} \mathrm{B}_{2} \operatorname{pin}_{2}, 2.5 \mathrm{~mol} \%$ [Ir(COD)(OMe $\left.)\right]_{2}, 5 \mathrm{~mol} \% \mathrm{tmphen}, 4 \mathrm{~mL}$ solvent, $70{ }^{\circ} \mathrm{C}, 18 \mathrm{~h}$

${ }^{\mathrm{a}}$ Isolated yields after purification by column chromatography. Average of three runs 
cross-coupling; this is a particular advantage as it simplifies the procedure and avoids undesired loss of material due to the instability of boronic esters during column chromatography.

While early optimization studies by Ishiyama, Takagi, Hartwig and Miyaura reported that the efficiency of iridium-catalyzed borylations were solvent dependent and that reactions conducted in hexane gave higher conversions than those in either DME or DMF [78], good conversions have recently been reported for phosphine and phosphonate directed C-H borylations conducted in more polar systems including THF and THF/dioxane [72, 74]. As such a comparison of the conversions obtained in THF with those in hexane showed that slightly lower conversions were obtained in THF over the same time (Table 2); this is entirely consistent with a recent high throughput optimization of iridium-catalyzed C-H borylations [101]. A comparison of the performance of in situ generated catalyst with preformed pre-catalyst revealed that polar solvents are suitable for borylations and that the lower conversion obtained with in situ generated catalyst is due the efficiency of catalyst assembly in different solvents rather than the performance of the actual catalyst $[101,102]$

As for the borylation of $\mathbf{3}$, borylation of $\mathbf{2 a - c}$ with HBpin under otherwise identical conditions resulted in good conversions over the same time but the yields were marginally lower than those obtained with $\mathrm{B}_{2} \mathrm{pin}_{2}$ and the performance of catalyst was also affected by the order of addition of the HBpin and ligand such that the highest conversions were obtained when the HBpin was added before the ligand. Interestingly, while formation of the meta-phosphonatesubstituted arylboronic esters 5a-c as the sole product was anticipated, Clark has recently investigated aryl phosphonate-directed ortho $\mathrm{C}-\mathrm{H}$ borylation and demonstrated that catalysts generated from 3,4,7,8-tetramethyl-1,10-phenanthroline, 4,4'-di-tert-butyl-2-2'-bipyridine or 2-picolylamine and $[\operatorname{Ir}(\mathrm{COD})(\mathrm{acac})]$ were also selective for borylation of diethyl $o$-tolylphosphonate at the meta position whereas phosphine-based catalysts were exclusively selective for ortho C-H borylation [70].

\subsection{Palladium Catalyzed Suzuki-Miyaura Cross-Cou- pling of meta-Phosphonate Substituted Arylbo- ronic Esters}

Having already demonstrated that ortho-phosphonate aryl and naphthylboronic esters can be used as nucleophilic partners in the Suzuki-Miyaura cross-coupling [69], the same protocol was applied to diversify $\mathbf{5 a - c}$ into a series of substituted biaryl monophosphonates by reaction with a range of aryl bromides. A brief optimization study using $\mathbf{5 a}$ and 4-bromoacetophenone as the benchmark combination with a $0.5 \mathrm{~mol} \%$ loading of XPHOS-based pre-catalyst $\mathbf{6}$, revealed that the highest conversions were obtained in a 2:1 mixture of THF and water at $70{ }^{\circ} \mathrm{C}$ with $\mathrm{K}_{3} \mathrm{PO}_{4}$ as base, while reactions conducted in DME, dry THF and toluene under otherwise identical conditions resulted in much lower conversions. A survey of the base revealed that similar conversions were also obtained with $\mathrm{K}_{2} \mathrm{CO}_{3}, \mathrm{Cs}_{2} \mathrm{CO}_{3}$ and $\mathrm{NaOH}$ whereas $\mathrm{NaOAc}, \mathrm{CsF}$ and $\mathrm{NBu}_{3}$ each gave poor conversions. Under these conditions, $\mathbf{6}$ catalyzed the reaction between electronrich, electron-poor, and sterically hindered electrophilic partners to afford reasonable yields of the corresponding biaryl monophosphonates as spectroscopically pure oils or solids after purification by column chromatography (Table 3). For example, the yields of biaryl monophosphonate obtained from the reaction between sterically demanding substrates such as 2-bromotoluene or 1-bromonaphthalene and 5a-c matched those obtained with electron deficient substrates. In all case, minor amounts of 2a-c (7-12\%) resulting from protodeboration of $\mathbf{5 a - c}$ were recovered during purification. At this stage, as the yields are only moderate speculation as to the origin of minor differences in conversions between the various substate combinations is not warranted and further studies will focus on identifying more efficient catalysts and protocols to improve the yields.

\section{Conclusions}

The iridium-catalyzed C-H borylation of diethyl phenylphosphonate with $\mathrm{B}_{2}$ pin $_{2}$ using catalyst generated from either $[\operatorname{Ir}(\mathrm{COD})(\mathrm{acac})]$ or $[\operatorname{Ir}(\mathrm{COD})(\mathrm{OMe})]_{2}$ and tmphen occurs under mild conditions but is nonselective and affords a statistical mixture of meta- and para-borylated products; in contrast, the phosphonate acts as a ortho-directing group with catalyst generated from $[\operatorname{Ir}(\mathrm{COD})(\mathrm{acac})]$ and $\left[\mathrm{P}\left[3,5-\left(\mathrm{CF}_{3}\right)_{2}-\mathrm{C}_{6} \mathrm{H}_{3}\right]_{3}\right.$ i.e. the ability of phosphonate to act as a directing group depends on the catalyst formulation which is probably associated with the capacity of the active trisboryl species to expand its coordination sphere to accommodate the phosphonate during the $\mathrm{C}-\mathrm{H}$ activation step. This borylation protocol was also applied to the synthesis of a series of meta-phosphonate-substituted arylboronic esters via a sterically-controlled regioselective C-H borylation of the corresponding 3-substituted aryl phosphonates; the resulting boronate esters were then used as nucleophilic coupling partners in a subsequent palladium-catalyzed Suzuki-Miyaura cross-coupling. This protocol avoids the use of pre-functionalized aryl phosphonates to prepare biaryl monophosphonates and the substitution pattern obtained with this $\mathrm{C}-\mathrm{H}$ borylation-cross coupling sequence complements that accessible via the phosphonate directed ortho $\mathrm{C}-\mathrm{H}$ borylation recent developed by Clark; taken together these sequences will provide access to a diverse range of highly substituted biaryl monophosphonates. To this end, studies are currently underway to improve the efficacy of the $\mathrm{C}-\mathrm{H}$ borylation, undertake kinetic investigations and optimize the 
Table 3 Suzuki-Miyaura cross-coupling between meta-phosphonate-substituted arylboronic esters (5a-c) and aryl bromides
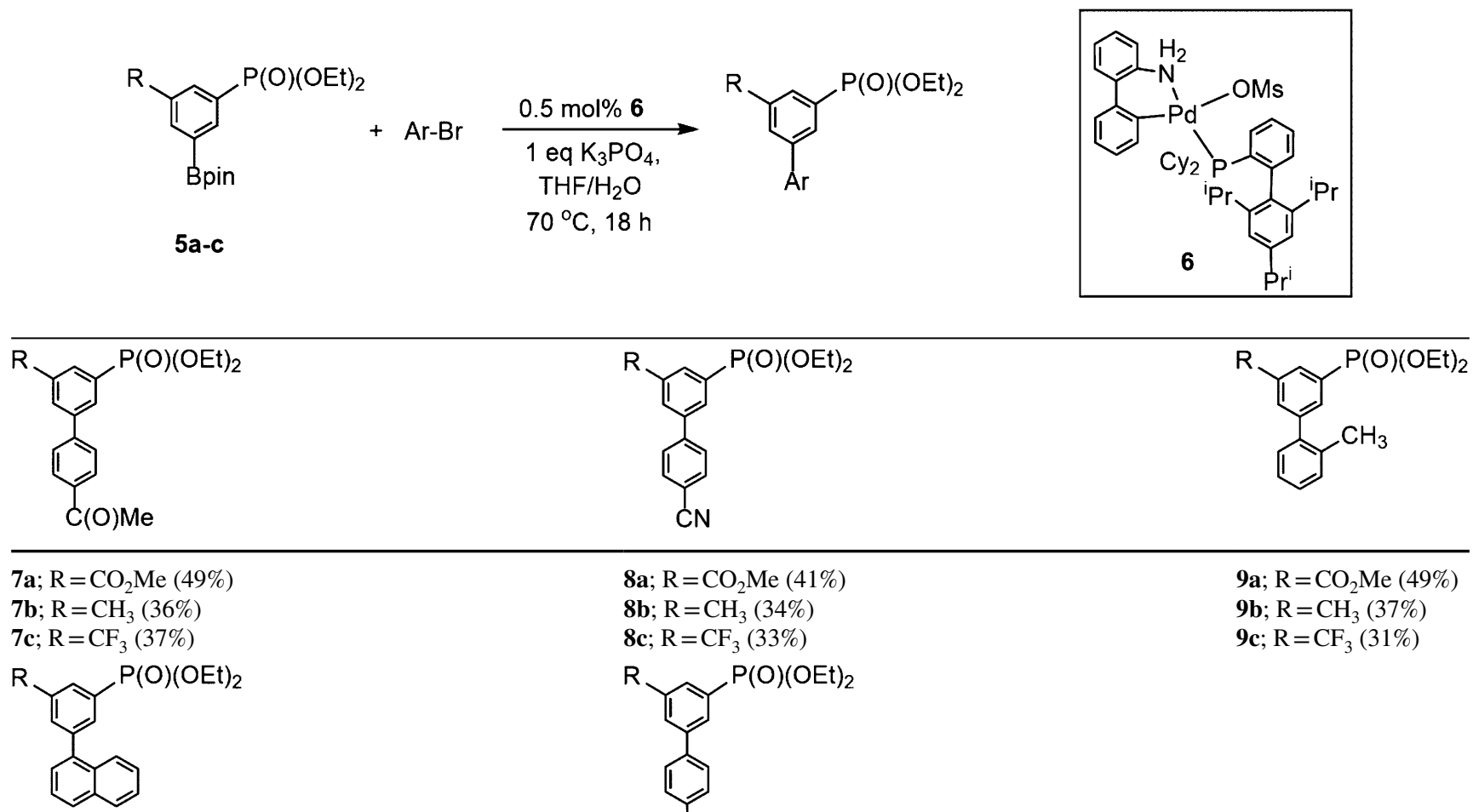

10a; $\mathrm{R}=\mathrm{CO}_{2} \mathrm{Me}(47 \%)$

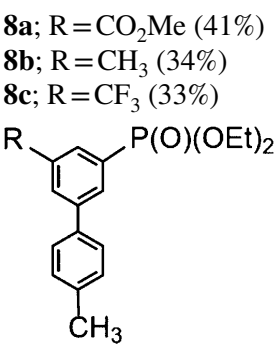

10b; $\mathrm{R}=\mathrm{CH}_{3}(39 \%)$

11a; $\mathrm{R}=\mathrm{CO}_{2} \mathrm{Me}(44 \%)$

10c; $\mathrm{R}=\mathrm{CF}_{3}(35 \%)$

11b; $\mathrm{R}=\mathrm{CH}_{3}(36 \%)$

Reaction conditions: $0.4 \mathrm{mmol}$ of 5a-c, $0.55 \mathrm{mmol} \mathrm{ArBr}, 0.5 \mathrm{~mol} \%$ 6, $0.74 \mathrm{mmol} \mathrm{K}_{3} \mathrm{PO}_{4}$, THF $(4 \mathrm{~mL})$, water $(2 \mathrm{~mL}), 70{ }^{\circ} \mathrm{C}, 18 \mathrm{~h}$

${ }^{\mathrm{a}}$ Isolated yields after purification by column chromatography. Average of three runs

Suzuki-Miyaura cross-coupling step, extend the methodology to the synthesis of a much broader range of aryl and heteroaryl monophosphonates and extend the phosphonate-based nucleophilic coupling partners to zinc and magnesium reagents.

\section{Experimental}

\subsection{General Procedures}

All chemicals were purchased from commercial suppliers and used without further purification except where indicated. Air-sensitive materials were manipulated using Schlenk line techniques and flame-dried glassware under nitrogen. Where necessary, solvents were dried prior to use. Dichloromethane was distilled from calcium hydride; ethanol from magnesium; 1,4-dioxane and tetrahydrofuran (THF) from sodium/ benzophenone; toluene and hexane from sodium. IR spectra were recorded on a Varian 800 FT-IR Scimitar Series infrared spectrometer. ${ }^{1} \mathrm{H},{ }^{13} \mathrm{C}\left\{{ }^{1} \mathrm{H}\right\}$, and ${ }^{31} \mathrm{P}\left\{{ }^{1} \mathrm{H}\right\}$ NMR spectra were recorded on a JEOL ECS 400, Bruker Avance 300,
Jeol Lambda 500, or a Bruker Avance $700 \mathrm{MHz}$ instrument. ${ }^{1} \mathrm{H}$ and ${ }^{13} \mathrm{C} \mathrm{NMR}$ were referenced against $\mathrm{CDCl}_{3}$. Mass spectrometry analysis was performed in-house using a Micromass LCT premier Mass Spectrometer in Electrospray (ES) mode or by the National Mass Spectrometry Facility in Swansea. Thin layer chromatography was performed on EM reagent $0.25 \mathrm{~mm}$ silica gel $60 \mathrm{~F}_{254}$ plates. Visualization was accomplished with UV light and aqueous potassium permanganate (VII) solution. Column chromatography of all purified products was carried out using Fluorochem LC3025 (40-63 $\mu \mathrm{m})$ silica gel. CHN analysis was performed on a Carlo Erba 1108 Elemental Analyser and controlled with Carlo Erba Eager 200 software.

\subsection{Experimental Procedures}

\subsubsection{General Procedure for the Synthesis of Phosphonates $1 a-c$}

A flame-dried nitrogen-filled Schlenk flask was charged with palladium acetate $(0.07 \mathrm{~g}, 0.3 \mathrm{mmol})$ and triphenylphosphine 
$(0.817 \mathrm{~g}, 3.10 \mathrm{mmol})$. Aryl bromide $(15.6 \mathrm{mmol})$, diisopropylethylamine $(17.0 \mathrm{~mL}, 97.3 \mathrm{mmol})$ and diethyl phosphite $(10.0 \mathrm{~mL}, 77.9 \mathrm{mmol})$ and dry ethanol $(60 \mathrm{~mL})$ were then added, and the reaction mixture was refluxed for $48 \mathrm{~h}$. The reaction mixture was left to cool to room temperature and diluted by the addition of diethyl ether $(200 \mathrm{~mL})$. Hydrochloric acid $(1 \mathrm{M}, 100 \mathrm{~mL})$ was added to wash the reaction mixture. The resulting aqueous layer was extracted with diethyl ether $(3 \times 200 \mathrm{~mL})$ and the diethyl ether extracts were washed with aqueous sodium hydroxide $(2.5 \mathrm{M}, 50 \mathrm{~mL})$, brine $(50 \mathrm{~mL})$, dried $\left(\mathrm{MgSO}_{4}\right)$, filtered and the solvent removed under reduced pressure afford a yellow oil. The crude product was purified by column chromatography (ethyl acetate: petrol 2:1).

\subsubsection{Methyl 3-(diethoxyphosphoryl)benzoate (2a)}

Prepared according to the general procedure described above using palladium acetate $(0.07 \mathrm{~g}, 0.3 \mathrm{mmol})$, triphenylphosphine $(0.817 \mathrm{~g}, 3.10 \mathrm{mmol})$, methyl 3-bromobenzoate $(3.35 \mathrm{~g}, 15.6 \mathrm{mmol})$, diisopropylethylamine $(17.0 \mathrm{~mL}$, $97.3 \mathrm{mmol})$, diethyl phosphite $(10.0 \mathrm{~mL}, 77.9 \mathrm{mmol})$ and dry ethanol $(60 \mathrm{~mL})$. The crude mixture was purified by column chromatography (ethyl acetate: hexanes $2: 1$ ) to afford 2a as colourless oil in 76\% yield (3.23 g, $11.9 \mathrm{mmol}) .{ }^{1} \mathrm{H}$ NMR $\left(300 \mathrm{MHz}, \mathrm{CDCl}_{3}\right.$ ): $\delta 8.39$ (dtd, $J=13.8,1.7,0.5 \mathrm{~Hz}$, $1 \mathrm{H}, \mathrm{Ar}-H) 8.13$ (ddd, $J=7.9,3.0,1.3 \mathrm{~Hz}, 1 \mathrm{H}, \mathrm{Ar}-H), 7.93$ (ddt, $J=12.9,7.6,1.4 \mathrm{~Hz}, 1 \mathrm{H}, \mathrm{Ar}-H$ ), 7.49 (tdd, $J=7.7$, 4.0, $0.4 \mathrm{~Hz}, 1 \mathrm{H}, \mathrm{Ar}-\mathrm{H}), 4.14-3.98\left(\mathrm{~m}, 4 \mathrm{H},-\mathrm{OCH}_{2} \mathrm{CH}_{3}\right)$, $3.85\left(\mathrm{~s}, 3 \mathrm{H}, \mathrm{C}(\mathrm{O})\left(\mathrm{OCH}_{3}\right), 1.25(\mathrm{td}, J=7.1,0.4 \mathrm{~Hz}, 6 \mathrm{H}\right.$, $\left.\mathrm{OCH}_{2} \mathrm{CH}_{3}\right) ;{ }^{13} \mathrm{C}$ NMR $\left(125 \mathrm{MHz}, \mathrm{CDCl}_{3}\right): \delta 166.0(\mathrm{~d}$, $J=2.0 \mathrm{~Hz}), 135.9(\mathrm{~d}, J=10.0 \mathrm{~Hz}), 133.2(\mathrm{~d}, J=2.8 \mathrm{~Hz})$, $132.7(\mathrm{~d}, J=10.9 \mathrm{~Hz}), 130.4(\mathrm{~d}, J=15.1 \mathrm{~Hz}), 130.2$ (d, $J=189.8 \mathrm{~Hz}), 128.7(\mathrm{~d}, \mathrm{~J}=14.9 \mathrm{~Hz}), 62.3(\mathrm{~d}, J=5.5 \mathrm{~Hz})$, $52.3(\mathrm{~s}), 16.3(\mathrm{~d}, J=6.4 \mathrm{~Hz}) ;{ }^{31} \mathrm{P} \mathrm{NMR}\left(162 \mathrm{MHz}, \mathrm{CDCl}_{3}\right)$ : $\delta 17.1$ (s); IR (neat) $\left(\mathrm{cm}^{-1}\right)$ : 3043.7, 2983.9, 2955.0, 2906.3, 1724.6, 1579.7, 1560.5, 1156.3, 990.2; $\mathrm{R}_{\mathrm{f}}$ (ethyl acetate: hexanes, $2: 1)=0.31$; HRMS $\left(\mathrm{ES}^{+}\right)$: exact mass calculated for $\mathrm{C}_{12} \mathrm{H}_{18} \mathrm{O}_{5} \mathrm{P}[\mathrm{M}+\mathrm{H}]^{+}$requires $m / z=273.0892$, found $\mathrm{m} / \mathrm{z}=273.0891$.

\subsubsection{Diethyl $m$-Tolylphosphonate (2b)}

Prepared according to the general procedure described above using palladium acetate $(0.07 \mathrm{~g}, 0.3 \mathrm{mmol})$, triphenylphosphine $(0.817 \mathrm{~g}, 3.10 \mathrm{mmol}), 3$-bromotoluene $(1.90 \mathrm{~mL}$, $15.6 \mathrm{mmol})$, diisopropylethylamine $(17.0 \mathrm{~mL}, 97.3 \mathrm{mmol})$, diethyl phosphite $(10.0 \mathrm{~mL}, 77.9 \mathrm{mmol})$ and dry ethanol $(60 \mathrm{~mL})$. The crude mixture was purified by column chromatography (ethyl acetate: hexanes $2: 1$ ) to afford $\mathbf{2 b}$ as colourless oil in $84 \%$ yield $(2.99 \mathrm{~g}, 13.1 \mathrm{mmol}) .{ }^{1} \mathrm{H}$ NMR $\left(300 \mathrm{MHz}, \mathrm{CDCl}_{3}\right): \delta 7.58-7.48(\mathrm{~m}, 2 \mathrm{H}, \mathrm{Ar}-H), 7.29$ $-7.26(\mathrm{~m}, 2 \mathrm{H}, \mathrm{Ar}-\mathrm{H}), 4.11-3.95\left(\mathrm{~m}, 4 \mathrm{H},-\mathrm{OCH}_{2} \mathrm{CH}_{3}\right)$, $2.31\left(\mathrm{~s}, 3 \mathrm{H},-\mathrm{CCH}_{3}\right), 1.24\left(\mathrm{t}, J=7.1 \mathrm{~Hz}, 6 \mathrm{H},-\mathrm{OCH}_{2} \mathrm{CH}_{3}\right)$; ${ }^{13} \mathrm{C} \mathrm{NMR}\left(125 \mathrm{MHz}, \mathrm{CDCl}_{3}\right): \delta 138.2(\mathrm{~d}, J=14.9 \mathrm{~Hz})$, $133.1(\mathrm{~d}, J=3.2 \mathrm{~Hz}), 132.2(\mathrm{~d}, J=10.0 \mathrm{~Hz}), 128.7$ (d, $J=9.7 \mathrm{~Hz}), 128.3(\mathrm{~d}, J=15.8 \mathrm{~Hz}), 128.1(\mathrm{~d}, J=186.8 \mathrm{~Hz})$, $62.0(\mathrm{~d}, J=5.4 \mathrm{~Hz}), 21.3(\mathrm{~s}), 16.3(\mathrm{~d}, J=6.5 \mathrm{~Hz}) ;{ }^{31} \mathrm{P} \mathrm{NMR}$ $\left(162 \mathrm{MHz}, \mathrm{CDCl}_{3}\right): \delta 19.3$ (s); IR (neat) $\left(\mathrm{cm}^{-1}\right): 3043.7$, 2981.8, 2905.8, 1724.6, 1579.7, 1582.5, 1150.9, 991.5; $\mathrm{R}_{\mathrm{f}}$ (ethyl acetate: hexanes, 2: 1) $=0.34$; HRMS $\left(\mathrm{ES}^{+}\right)$: exact mass calculated for $\mathrm{C}_{11} \mathrm{H}_{17} \mathrm{O}_{3} \mathrm{P}[\mathrm{M}+\mathrm{Na}]^{+}$requires $\mathrm{m} / \mathrm{z}=251.0813$, found $\mathrm{m} / \mathrm{z}=251.0814$.

\subsubsection{Diethyl (3-(Trifluoromethyl)phenyl)phosphonate (2c)}

Prepared according to the general procedure described above using palladium acetate $(0.07 \mathrm{~g}, 0.3 \mathrm{mmol})$, triphenylphosphine $(0.817 \mathrm{~g}, 3.10 \mathrm{mmol})$, 3-bromobenzotrifluoride $(2.18 \mathrm{~mL}, 15.6 \mathrm{mmol})$, diisopropylethylamine $(17.0 \mathrm{~mL}$, $97.3 \mathrm{mmol})$, diethyl phosphite $(10.0 \mathrm{~mL}, 77.9 \mathrm{mmol})$ and dry ethanol $(60 \mathrm{~mL})$. The crude mixture was purified by column chromatography (ethyl acetate: hexanes 2:1) to afford 2c as colourless oil in $91 \%$ yield $(4.01 \mathrm{~g}, 14.2 \mathrm{mmol}) .{ }^{1} \mathrm{H}$ NMR (300 MHz, $\left.\mathrm{CDCl}_{3}\right): \delta 8.00$ (d, $J=13.7 \mathrm{~Hz}, 1 \mathrm{H}, \mathrm{Ar}-H$ ), 7.93 (dd, $J=13.0,7.6 \mathrm{~Hz}, 1 \mathrm{H}, \mathrm{Ar}-H), 7.73$ (d, $J=7.8 \mathrm{~Hz}$, $1 \mathrm{H}, \mathrm{Ar}-H), 7.54(\mathrm{td}, J=7.8,3.8 \mathrm{~Hz}, 1 \mathrm{H}, \mathrm{Ar}-H), 4.16-3.99$ (m, $4 \mathrm{H},-\mathrm{OCH}_{2} \mathrm{CH}_{3}$ ), 1.26 (t, $J=7.2 \mathrm{~Hz}, 6 \mathrm{H},-\mathrm{OCH}_{2} \mathrm{CH}_{3}$ ); ${ }^{13} \mathrm{C} \mathrm{NMR}\left(125 \mathrm{MHz}, \mathrm{CDCl}_{3}\right): \delta 134.8(\mathrm{~d}, J=9.4 \mathrm{~Hz}), 130.8$ (dd, $J=32.9$ and $15.7 \mathrm{~Hz}), 130.0(\mathrm{~d}, J=190.4 \mathrm{~Hz}), 129.1$ (s), $129.1-128.7(\mathrm{~m}), 128.4(\mathrm{dq}, J=11.2$ and $3.6 \mathrm{~Hz})$, 123.5 (qd, $J=272.6$ and $2.2 \mathrm{~Hz}), 62.4(\mathrm{~d}, J=5.5 \mathrm{~Hz}), 16.1$ $(\mathrm{d}, J=6.3 \mathrm{~Hz}) ;{ }^{31} \mathrm{P}$ NMR $\left(162 \mathrm{MHz}, \mathrm{CDCl}_{3}\right): \delta 16.3(\mathrm{~s})$ IR (neat) $\left(\mathrm{cm}^{-1}\right): 3049.1,2985.7,2908.7,1608.3,1153.5$, 989.5; $\mathrm{R}_{\mathrm{f}}$ (ethyl acetate: petrol, 2: 1$)=0.29$; $\mathrm{HRMS}\left(\mathrm{ES}^{+}\right)$: exact mass calculated for $\mathrm{C}_{11} \mathrm{H}_{14} \mathrm{O}_{3} \mathrm{PF}_{3}[\mathrm{M}+\mathrm{H}]^{+}$requires $\mathrm{m} / \mathrm{z}=283.0711$, found $\mathrm{m} / \mathrm{z}=283.0705$.

\subsubsection{General Procedure for the Iridium-Catalyzed Boryla- tion of Diethyl Phenylphosphonate (3) with $\mathrm{B}_{2} \mathrm{pin}_{2}$}

A flame-dried nitrogen-filled Schlenk flask was charged with iridium precursor $(2.5 \mathrm{~mol} \%)$, ligand $(2.5 \mathrm{~mol} \%)$ and bis(pinacolato)diboron $(0.069 \mathrm{~g}, 0.28 \mathrm{mmol})$ or pinacolborane $(0.0947 \mathrm{~g}, 0.74 \mathrm{mmol})$. Diethyl phenylphosphonate $(0.090 \mathrm{~g}, 0.085 \mathrm{~mL}, 0.37 \mathrm{mmol})$ and dry solvent $(4 \mathrm{~mL})$ were then added, and the reaction mixture stirred for the allocated time at the specified temperature. After this time, the resulting solution was left to cool to room temperature, diluted by the addition of acetonitrile $(2 \mathrm{~mL})$, the resulting solution passed through a silica plug and the solvent removed under reduced pressure. The crude product was dissolved in $\mathrm{CDCl}_{3}$ and analyzed by ${ }^{31} \mathrm{P}$ and ${ }^{1} \mathrm{H}$ NMR spectroscopy to quantify the composition and determine the selectivity profile. 


\subsubsection{General Procedure for the Iridium-catalyzed Boryla- tion of Diethyl Phenylphosphonate (3) with HBpin}

Addition of tmphen before HBpin- A flame-dried nitrogenfilled Schlenk flask was charged with $[\operatorname{Ir}(\mathrm{COD})(\mathrm{OMe})]_{2}$ $(0.0061 \mathrm{~g}, 0.0092 \mathrm{mmol}, 2.5 \mathrm{~mol} \%)$, tmphen $(0.0043 \mathrm{~g}$ $0.018 \mathrm{mmol}, 5 \mathrm{~mol} \%)$ and dry hexane $(4 \mathrm{ml})$. After stirring for $c a$. two minute, pinacolborane $(0.0947 \mathrm{~g}, 0.74 \mathrm{mmol})$ was added followed by diethyl phenylphosphonate $(0.090 \mathrm{~g}$, $0.085 \mathrm{~mL}, 0.37 \mathrm{mmol}$ ) and the reaction mixture stirred for the allocated time at the specified temperature. After this time, the resulting solution was left to cool to room temperature, diluted by the addition of acetonitrile $(2 \mathrm{~mL})$, the resulting solution passed through a silica plug and the solvent removed under reduced pressure. The crude product was dissolved in $\mathrm{CDCl}_{3}$ and analyzed by ${ }^{31} \mathrm{P}$ and ${ }^{1} \mathrm{H}$ NMR spectroscopy to quantify the composition and determine the selectivity profile.

Addition of HBpin before tmphen- A flame-dried nitrogen-filled Schlenk flask was charged with [Ir(COD) $(\mathrm{OMe})]_{2}(0.0061 \mathrm{~g}, 0.0092 \mathrm{mmol}, 2.5 \mathrm{~mol} \%)$, pinacolborane $(0.0947 \mathrm{~g}, 0.74 \mathrm{mmol})$ and dry hexane $(4 \mathrm{ml})$. After stirring for $c a$. two minute, tmphen $(0.0043 \mathrm{~g} 0.018 \mathrm{mmol}$, $5 \mathrm{~mol} \%$ ) was added followed immediately by diethyl phenylphosphonate $(0.090 \mathrm{~g}, 0.085 \mathrm{~mL}, 0.37 \mathrm{mmol})$ and the reaction mixture stirred for the allocated time at the specified temperature. After this time, the resulting solution was left to cool to room temperature, diluted by the addition of acetonitrile $(2 \mathrm{~mL})$, the resulting solution passed through a silica plug and the solvent removed under reduced pressure. The crude product was dissolved in $\mathrm{CDCl}_{3}$ and analyzed by ${ }^{31} \mathrm{P}$ and ${ }^{1} \mathrm{H}$ NMR spectroscopy to quantify the composition and determine the selectivity profile.

\subsubsection{General Procedure for the Synthesis of 5a-c via Irid- ium Catalyzed Borylation of 2a-c}

A flame-dried nitrogen-filled Schlenk flask was charged with (1,5-cyclooctadiene)(methoxy)iridium(I) dimer $(0.0061 \mathrm{~g}$, $0.00918 \mathrm{mmol}), 3,4,7,8$-tetramethyl-1,10-phenanthroline $(0.00434 \mathrm{~g}, 0.0184 \mathrm{mmol})$ and bis(pinacolato)diboron $(0.069 \mathrm{~g}, 0.28 \mathrm{mmol})$. The 3 -substituted diethyl phenylphosphonate $(0.37 \mathrm{mmol})$ and dry hexane $(4 \mathrm{~mL})$ were then added, and the reaction mixture stirred for $18 \mathrm{~h}$ at $70{ }^{\circ} \mathrm{C}$. After this time, the resulting solution was left to cool to room temperature and diluted by the addition of acetonitrile $(2 \mathrm{~mL})$. The resulting solution was passed through a silica plug and the solvent removed under reduced pressure to leave a yellow oil. The crude product was used without further purification.
4.2.8 Synthesis of Methyl 3-(Diethoxyphosphoryl)-5-(4,4,5, 5-Tetramethyl-1,3,2-Dioxaborolan-2-yl)Benzoate (5a)

Prepared according to the general procedure described above using (1,5-cyclooctadiene)(methoxy)iridium(I) dimer (0.0061 g, $0.00918 \mathrm{mmol}), 3,4,7,8$-tetramethyl-1,10-phenanthroline $(0.00434 \mathrm{~g}, 0.0184 \mathrm{mmol})$, bis(pinacolato)diboron $(0.069 \mathrm{~g}, 0.28 \mathrm{mmol})$, methyl 3-(diethoxyphosphoryl) benzoate $(0.106 \mathrm{~g}, 0.37 \mathrm{mmol})$ and dry hexane $(4 \mathrm{~mL}) .{ }^{1} \mathrm{H}$ NMR $\left(300 \mathrm{MHz}, \mathrm{CDCl}_{3}\right): \delta 8.59(\mathrm{~s}, 1 \mathrm{H}, \mathrm{Ar}-H), 8.51(\mathrm{~d}$, $J=13.2 \mathrm{~Hz}, 1 \mathrm{H}, \mathrm{Ar}-H), 8.40(\mathrm{~d}, J=12.5 \mathrm{~Hz}, 1 \mathrm{H}, \mathrm{Ar}-H)$, $4.22-4.03\left(\mathrm{~m}, 4 \mathrm{H},-\mathrm{OCH}_{2} \mathrm{CH}_{3}\right), 3.91\left(\mathrm{~s}, 3 \mathrm{H},-\mathrm{OCH}_{3}\right), 1.32$ (s, $\left.12 \mathrm{H}, \mathrm{Bpin}-\mathrm{CH}_{3}\right), 1.30\left(\mathrm{t}, J=7.4 \mathrm{~Hz}, 6 \mathrm{H},-\mathrm{OCH}_{2} \mathrm{CH}_{3}\right) ;{ }^{31} \mathrm{P}$ $\operatorname{NMR}\left(162 \mathrm{MHz}, \mathrm{CDCl}_{3}\right): \delta 17.5(\mathrm{~s}) ;{ }^{11} \mathrm{~B}\left(193 \mathrm{MHz}, \mathrm{CDCl}_{3}\right)$ : $\delta 30.1$; HRMS $\left(\mathrm{ES}^{+}\right)$: exact mass calculated for $\mathrm{C}_{18} \mathrm{H}_{29} \mathrm{BO}_{7} \mathrm{P}$ $[\mathrm{M}+\mathrm{H}]^{+}$requires $m / z=399.1744$, found $m / z=399.1747$.

\subsubsection{Synthesis of Diethyl 3-Methyl-[5-(4,4,5,5-Tetra- methyl-1,3,2-Dioxaborolan-2-yl)]Phenyl Phospho- nate $(5 b)$}

Prepared according to the general procedure described above using (1,5-cyclooctadiene)(methoxy)iridium(I) dimer (0.0061 g, $0.00918 \mathrm{mmol}), 3,4,7,8$-tetramethyl-1,10-phenanthroline $(0.00434 \mathrm{~g}, 0.0184 \mathrm{mmol})$, bis(pinacolato)diboron $(0.069 \mathrm{~g}, 0.28 \mathrm{mmol})$, diethyl $m$-tolylphosphonate $(0.084 \mathrm{~g}$, $0.37 \mathrm{mmol})$ and dry hexane $(4 \mathrm{~mL}) .{ }^{1} \mathrm{H}$ NMR $(300 \mathrm{MHz}$, $\left.\mathrm{CDCl}_{3}\right): \delta 7.94(\mathrm{~d}, J=13.9 \mathrm{~Hz}, 1 \mathrm{H}, \mathrm{Ar}-H), 7.70(\mathrm{~s}, 1 \mathrm{H}$, $\operatorname{Ar}-H), 7.65(\mathrm{~d}, J=14.5 \mathrm{~Hz}, 1 \mathrm{H}, \mathrm{Ar}-H), 4.14-3.94(\mathrm{~m}, 4 \mathrm{H}$, $\left.-\mathrm{OCH}_{2} \mathrm{CH}_{3}\right), 2.31\left(\mathrm{~s}, 3 \mathrm{H},-\mathrm{CH}_{3}\right), 1.27\left(\mathrm{~s}, 12 \mathrm{H}, \mathrm{Bpin}-\mathrm{CH}_{3}\right)$, $1.21\left(\mathrm{t}, J=7.5 \mathrm{~Hz}, 6 \mathrm{H},-\mathrm{OCH}_{2} \mathrm{CH}_{3}\right) ;{ }^{31} \mathrm{P}$ NMR $(162 \mathrm{MHz}$, $\left.\mathrm{CDCl}_{3}\right): \delta 19.4(\mathrm{~s}) ;{ }^{11} \mathrm{~B}\left(193 \mathrm{MHz}, \mathrm{CDCl}_{3}\right): \delta 22.4 ; \mathrm{HRMS}$ $\left(\mathrm{ES}^{+}\right)$: exact mass calculated for $\mathrm{C}_{17} \mathrm{H}_{29} \mathrm{BO}_{7} \mathrm{P}[\mathrm{M}+\mathrm{H}]^{+}$ requires $m / z=355.1846$, found $m / z=355.1851$.

\subsubsection{Synthesis of Diethyl (3-(4,4,5,5-Tetra- methyl-1,3,2-Dioxaborolan-2-yl)-5- (Trifluorome- thyl)Phenyl)Phosphonate (5c)}

Prepared according to the general procedure described above using iridium ([1,5-cyclooctadiene][methoxy]) dimer (0.0061 g, $0.00918 \mathrm{mmol}$ ) 3,4,7,8-tetramethyl-1,10-phenanthroline $(0.00434 \mathrm{~g}, 0.0184 \mathrm{mmol})$ and bis(pinacolato)diboron $(0.069 \mathrm{~g}, 0.28 \mathrm{mmol})$, diethyl (3-(trifluoromethyl)phenyl) phosphonate $(0.104 \mathrm{~g}, 0.37 \mathrm{mmol})$ and dry hexane $(4 \mathrm{~mL})$. ${ }^{1} \mathrm{H}$ NMR $\left(300 \mathrm{MHz}, \mathrm{CDCl}_{3}\right): \delta 7.93(\mathrm{~d}, J=14.1 \mathrm{~Hz}, 1 \mathrm{H}$, Ar- $H), 7.68(\mathrm{~s}, 1 \mathrm{H}, \mathrm{Ar}-H), 7.64$ (d, $J=14.4 \mathrm{~Hz}, 1 \mathrm{H}, \mathrm{Ar}-H)$, $4.13-3.91\left(\mathrm{~m}, 4 \mathrm{H},-\mathrm{OCH}_{2} \mathrm{CH}_{3}\right), 2.30\left(\mathrm{~s}, 3 \mathrm{H},-\mathrm{CH}_{3}\right), 1.26$ (s, $12 \mathrm{H}$, Bpin- $\left.\mathrm{CH}_{3}\right), 1.19\left(\mathrm{t}, J=7.2 \mathrm{~Hz}, 6 \mathrm{H},-\mathrm{OCH}_{2} \mathrm{CH}_{3}\right)$; ${ }^{31} \mathrm{P}$ NMR (162 MHz, $\left.\mathrm{CDCl}_{3}\right): \delta 18.2(\mathrm{~s}) ;{ }^{11} \mathrm{~B}(193 \mathrm{MHz}$, $\left.\mathrm{CDCl}_{3}\right): \delta 27.6$; HRMS $\left(\mathrm{ES}^{+}\right)$: exact mass calculated for 
$\mathrm{C}_{17} \mathrm{H}_{26} \mathrm{BF}_{3} \mathrm{O}_{5} \mathrm{P}[\mathrm{M}+\mathrm{H}]^{+}$requires $m / z=409.1563$, found $\mathrm{m} / \mathrm{z}=409.1565$.

\subsubsection{General Procedure for the Palladium-Catalyzed Suzuki-Miyaura Cross-Coupling Between $m$-Phos- phonate-Substituted Arylboronic Esters (5a-c) and Aryl Bromides}

A flame dried Schlenk flask was cooled to room temperature under vacuum, backfilled with nitrogen and charged with aryl bromide $(0.551 \mathrm{mmol})$, precatalyst $6(0.5 \mathrm{~mol} \%$, $0.0015 \mathrm{~g}, 1.84 \mu \mathrm{mol}), \mathrm{K}_{3} \mathrm{PO}_{4}(0.17 \mathrm{~g}, 0.734 \mathrm{mmol})$ and THF $(4 \mathrm{~mL})$. Phosphonate $\mathbf{5 a - c}(0.37 \mathrm{mmol})$ and water $(2 \mathrm{ml})$ were then added, and resulting mixture heated for $18 \mathrm{~h}$ at $70{ }^{\circ} \mathrm{C}$. After this time, the reaction mixture was cooled to room temperature, diluted with diethyl ether $(10 \mathrm{~mL})$ and filtered through a silica plug by flushing with $\mathrm{CH}_{2} \mathrm{Cl}_{2} / \mathrm{MeOH}$ $(9 / 1)$. The solvent was removed under reduced pressure and the product purified by column chromatography ethyl acetate/hexane (2/1) as eluent.

\subsubsection{Methyl 4'-Acetyl-5-(diethoxyphosphoryl)-[1,1'-biph enyl]-3-Carboxylate (7a)}

The general procedure described above was followed using 4-bromoacetophenone $(0.110 \mathrm{~g}, 0.551 \mathrm{mmol})$, pre-catalyst $6(0.5 \mathrm{~mol} \%, 0.0015 \mathrm{~g}, 1.84 \mu \mathrm{mol})$ and $\mathrm{K}_{3} \mathrm{PO}_{4}(0.17 \mathrm{~g}$, $0.734 \mathrm{mmol}), 5 \mathrm{a}(0.147 \mathrm{~g}, 0.37 \mathrm{mmol})$, THF ( $4 \mathrm{~mL})$ and water $(2 \mathrm{~mL})$. The crude residue was purified by column chromatography (ethyl acetate: hexanes 2/1) to afford methyl $7 \mathbf{a}$ as an off-white solid in $49 \%$ yield $(0.071 \mathrm{~g}$, $0.181 \mathrm{mmol}) .{ }^{1} \mathrm{H} \mathrm{NMR}\left(300 \mathrm{MHz}, \mathrm{CDCl}_{3}\right): \delta 8.47(\mathrm{dt}$, $J=6.5 \mathrm{~Hz}, 1 \mathrm{H}, \mathrm{Ar}-H), 8.27$ (dt, $J=13.4 \mathrm{~Hz}, 1 \mathrm{H}, \mathrm{Ar}-H$ ), 8.07 (dt, $J=8.9 \mathrm{~Hz}, 4 \mathrm{H}, \mathrm{Ar}-H), 7.75$ (dt, $J=8.5 \mathrm{~Hz}, 2 \mathrm{H}$, $\mathrm{Ar}-\mathrm{H}), 4.34-4.04\left(\mathrm{~m}, 4 \mathrm{H},-\mathrm{CH}_{2}\right), 3.98\left(\mathrm{~s}, 3 \mathrm{H},-\mathrm{OCH}_{3}\right), 2.65$ (s, $\left.3 \mathrm{H},-\mathrm{COCH}_{3}\right), 1.36\left(\mathrm{t}, J=7.14 \mathrm{~Hz}, 6 \mathrm{H},-\mathrm{OCH}_{2} \mathrm{CH}_{3}\right)$; ${ }^{13} \mathrm{C}$ NMR (75 MHz, $\mathrm{CDCl}_{3}$ ): $\delta 197.6(\mathrm{~s}), 166.07$ (s), 143.5, 140.8, 136.8 (s), 134.7 (d, J = 8.0 Hz), 132.0 (s), 131.8 (s), 131.6 (s), $131.4(\mathrm{~s}), 130.9$ (d, $J=188.2 \mathrm{~Hz}), 129.2$ (s), 127.56(s), 62.7 (d, $J=20.3 \mathrm{~Hz}), 52.7(\mathrm{~s}), 26.9$ (s), 16.5 (d, $J=24.8 \mathrm{~Hz}) ;{ }^{31} \mathrm{P} \mathrm{NMR}\left(162 \mathrm{MHz}, \mathrm{CDCl}_{3}\right): \delta 16.7$ (s); IR (neat) $\left(\mathrm{cm}^{-1}\right): 2986.4,1724.4,1682.3,1606.6,1539.1$, 1153.1, 991.3; $\mathrm{R}_{\mathrm{f}}$ (ethyl acetate: hexanes, $2: 1$ ) $=0.20$; Anal. calcd. for $\mathrm{C}_{20} \mathrm{H}_{23} \mathrm{O}_{6} \mathrm{P} ; \mathrm{C}, 61.54 ; \mathrm{H}, 5$.94. Found: $\mathrm{C}, 61.98$; $\mathrm{H}$ 6.36; HRMS (ES ${ }^{+}$): exact mass calculated for $\mathrm{C}_{20} \mathrm{H}_{24} \mathrm{O}_{6} \mathrm{P}$ $[\mathrm{M}+\mathrm{H}]^{+}$requires $m / z=391.1311$, found $m / z=391.1311$.

\subsubsection{Diethyl (4'-Acetyl-5-Methyl-[1,1'-Biphenyl]-3-yl) Phosphonate (7b)}

The general procedure described above was followed using 4-bromoacetophenone $(0.110 \mathrm{~g}, 0.551 \mathrm{mmol})$, pre-catalyst $6(0.5 \mathrm{~mol} \%, 0.0015 \mathrm{~g}, 1.84 \mu \mathrm{mol}), \mathrm{K}_{3} \mathrm{PO}_{4}$ $(0.17 \mathrm{~g}, 0.734 \mathrm{mmol}), \mathbf{6 b}(0.131 \mathrm{~g}, 0.37 \mathrm{mmol}), \mathrm{THF}(4 \mathrm{~mL})$ and water $(2 \mathrm{~mL})$. The crude residue was purified by column chromatography (ethyl acetate: hexanes, 2/1) to afford 7b as a white solid in $36 \%$ yield $(0.046 \mathrm{~g}, 0.133 \mathrm{mmol})$. 1H NMR (300 MHz, $\left.\mathrm{CDCl}_{3}\right): \delta 8.02(\mathrm{dt}, J=7.8 \mathrm{~Hz}, 1 \mathrm{H}$, $\mathrm{Ar}-H), 7.85(\mathrm{~d}, J=7.7 \mathrm{~Hz}, 1 \mathrm{H}, \mathrm{Ar}-H), 7.67(\mathrm{dt}, J=7.8 \mathrm{~Hz}$, $1 \mathrm{H}, \mathrm{Ar}-H), 7.60(\mathrm{~d}, J=7.1 \mathrm{~Hz}, 1 \mathrm{H}, \mathrm{Ar}-H), 7.43-7.41(\mathrm{~m}$, $3 \mathrm{H}, \mathrm{Ar}-\mathrm{H}), 4.16-3.98$ (m, 4H, $-\mathrm{CH}_{2}$ ), 2.57 (s, 3H, Ar- $\mathrm{CH}_{3}$ ), $2.41\left(\mathrm{~s}, 3 \mathrm{H},-\mathrm{CH}_{3}\right), 1.28\left(\mathrm{t}, J=7.5 \mathrm{~Hz}, 6 \mathrm{H},-\mathrm{OCH}_{2} \mathrm{CH}_{3}\right) ;{ }^{13} \mathrm{C}$ NMR (75 MHz, $\left.\mathrm{CDCl}_{3}\right): \delta 197.9(\mathrm{~s}), 144.8(\mathrm{~d}, J=8.7 \mathrm{~Hz})$, 140.4 (s), 140.3 (s), 139.3 (d, $J=8.4 \mathrm{~Hz}), 136.3$ (s), 132.1 (d, $J=8.9 \mathrm{~Hz}), 129.9(\mathrm{~d}, J=9.1 \mathrm{~Hz}), 129.1(\mathrm{~s}), 128.8(\mathrm{~d}$, $J=187.6 \mathrm{~Hz}), 128.8(\mathrm{~d}, J=8.4 \mathrm{~Hz}) 127.9(\mathrm{~d}, J=9.0 \mathrm{~Hz})$, $127.5(\mathrm{~s}), 62.4(\mathrm{~d}, J=20.3 \mathrm{~Hz}), 26.8(\mathrm{~s}), 21.6(\mathrm{~d}, J=8.7 \mathrm{~Hz})$, $16.6(\mathrm{~d}, J=26.0 \mathrm{~Hz}) ;{ }^{31} \mathrm{P}$ NMR $\left(162 \mathrm{MHz}, \mathrm{CDCl}_{3}\right): \delta 18.7$ (s); IR (neat); $\left(\mathrm{cm}^{-1}\right)$ : 2985.7, 1654.6, 1593.2, 1150.8, 989.9; $\mathrm{R}_{\mathrm{f}}$ (ethyl acetate: hexanes, 2: 1) =0.48; Anal. calcd. for $\mathrm{C}_{19} \mathrm{H}_{23} \mathrm{O}_{4} \mathrm{P} ; \mathrm{C}, 65.70 ; \mathrm{H}, 6.69$. Found: $\mathrm{C}, 66.13 ; \mathrm{H}$ 7.07; HRMS (ES ${ }^{+}$): exact mass calculated for $\mathrm{C}_{19} \mathrm{H}_{24} \mathrm{O}_{4} \mathrm{P}$ $[\mathrm{M}+\mathrm{H}]^{+}$requires $\mathrm{m} / \mathrm{z}=347.1412$, found $\mathrm{m} / \mathrm{z}=347.1413$.

\subsubsection{Diethyl (4'-Acetyl-5-(Trifluoromethyl)-[1,1'-Biphenyl ]-3-yl)Phosphonate (7c)}

The general procedure described above was followed using 4-bromoacetophenone $(0.110 \mathrm{~g}, 0.551 \mathrm{mmol})$, pre-catalyst $6(0.5 \mathrm{~mol} \%, 0.0015 \mathrm{~g}, 1.84 \mu \mathrm{mol}), \mathrm{K}_{3} \mathrm{PO}_{4}(0.17 \mathrm{~g}$, $0.734 \mathrm{mmol}), \mathbf{5 c}(0.151 \mathrm{~g}, 0.37 \mathrm{mmol})$, THF $(4 \mathrm{~mL})$ and water $(2 \mathrm{~mL})$. The crude residue was purified by column chromatography (ethyl acetate: hexanes $2 / 1$ ) to afford $\mathbf{7 c}$ as a colourless oil in $39 \%$ yield $(0.058 \mathrm{~g}, 0.144 \mathrm{mmol}) .{ }^{1} \mathrm{H}$ NMR $\left(300 \mathrm{MHz}, \mathrm{CDCl}_{3}\right): \delta 8.18(\mathrm{~d}, J=12.0 \mathrm{~Hz}, 1 \mathrm{H}, \mathrm{Ar}-H), 7.98$ (m, 4H, Ar-H), 7.65 (d, J=9.0 Hz, 2H, Ar-H), $4.13(\mathrm{~m}, 4 \mathrm{H}$, $\left.-\mathrm{OCH}_{2} \mathrm{CH}_{3}\right), 2.59\left(\mathrm{~s}, 3 \mathrm{H}, \mathrm{C}(\mathrm{O}) \mathrm{CH}_{3}\right), 1.30(\mathrm{t}, J=6.0 \mathrm{~Hz}, 6 \mathrm{H}$, $-\mathrm{OCH}_{2} \mathrm{CH}_{3}$ ); ${ }^{13} \mathrm{C} \mathrm{NMR}\left(75 \mathrm{MHz}, \mathrm{CDCl}_{3}\right): \delta 197.4(\mathrm{~s}), 142.9$ (s), $141.3(\mathrm{~d}, J=15.0 \mathrm{~Hz}), 136.9(\mathrm{~s}), 133.7(\mathrm{~d}, J=10.0 \mathrm{~Hz})$, $131.9(\mathrm{~m}), 130.4(\mathrm{~s}), 129.2(\mathrm{~s}), 127.9(\mathrm{~m}), 127.7(\mathrm{~m}), 127.5$ (s), 123.9 (q, $J=272.0 \mathrm{~Hz}), 62.7(\mathrm{~d}, J=5.0 \mathrm{~Hz}), 25.8(\mathrm{~d}$, $J=6.0 \mathrm{~Hz}), 16.4(\mathrm{~d}, \mathrm{~J}=26.0 \mathrm{~Hz}) ;{ }^{31} \mathrm{P}$ NMR $(162 \mathrm{MHz}$, $\left.\mathrm{CDCl}_{3}\right): \delta 15.8$ (s); IR (neat) $\left(\mathrm{cm}^{-1}\right): 2984.5,1685.1,1607.1$, 1564.2, 1154.1, 991.8; HRMS (ES $\left.{ }^{+}\right)$: exact mass calculated for $\mathrm{C}_{19} \mathrm{H}_{20} \mathrm{~F}_{3} \mathrm{O}_{4} \mathrm{P}[\mathrm{M}+\mathrm{H}]^{+}$requires $\mathrm{m} / \mathrm{z}=401.1129$, found $\mathrm{m} / \mathrm{z}=401.1129$.

\subsubsection{Methyl 4'-Cyano-5-(Diethoxyphosphoryl)-[1,1'-Biph enyl]-3-Carboxylate (8a)}

The general procedure described above was followed using 4-bromobenzonitrile $(0.100 \mathrm{~g}, 0.551 \mathrm{mmol}), 6(0.5 \mathrm{~mol} \%$, $0.0015 \mathrm{~g}, 1.84 \mu \mathrm{mol}), \mathrm{K}_{3} \mathrm{PO}_{4}(0.17 \mathrm{~g}, 0.734 \mathrm{mmol}), 5 \mathbf{a}$ $(0.147 \mathrm{~g}, 0.37 \mathrm{mmol})$, THF $(4 \mathrm{~mL})$ and water $(2 \mathrm{~mL})$. The crude residue was purified by column chromatography 
(ethyl acetate: hexanes 2/1) to afford methyl 8a as an offwhite solid in $41 \%$ yield $(0.057 \mathrm{~g}, 0.151 \mathrm{mmol}) .{ }^{1} \mathrm{H}$ NMR (300 $\mathrm{MHz}, \mathrm{CDCl}_{3}$ ): $\delta 8.48(\mathrm{~d}, J=12.2,1 \mathrm{H}, \mathrm{Ar}-H), 8.44$ $(\mathrm{s}, 1 \mathrm{H}, \mathrm{Ar}-H), 8.24(\mathrm{~d}, J=14.8 \mathrm{~Hz}, 1 \mathrm{H}, \mathrm{Ar}-H), 7.77$ (d, $J=1.9 \mathrm{~Hz}, 4 \mathrm{H}, \mathrm{Ar}-H), 4.27-4.09\left(\mathrm{~m}, 4 \mathrm{H},-\mathrm{CH}_{2}\right), 3.99$ (s, $\left.3 \mathrm{H},-\mathrm{OCH}_{3}\right), 1.58\left(\mathrm{t}, J=7.7 \mathrm{~Hz}, 6 \mathrm{H},-\mathrm{OCH}_{2} \mathrm{CH}_{3}\right) ;{ }^{31} \mathrm{P} \mathrm{NMR}$ $\left(162 \mathrm{MHz} \mathrm{CDCl}_{3}\right): \delta 16.4$ (s); IR (neat) $\left(\mathrm{cm}^{-1}\right): 2985.8$, 2235.7, 1682.3, 1648.9, 1539.1, 1155.8, 993.4; $\mathrm{R}_{\mathrm{f}}$ (ethyl acetate: hexanes, 2: 1) =0.23; Anal. calcd. for $\mathrm{C}_{19} \mathrm{H}_{20} \mathrm{NO}_{5} \mathrm{P}$; C, 61.13; H, 5.40; N, 3.75. Found: C, 61.54; H 5.79, N, 4.12; HRMS $\left(\mathrm{ES}^{+}\right)$: exact mass calculated for $\mathrm{C}_{19} \mathrm{H}_{21} \mathrm{NO}_{5} \mathrm{P}$ $[\mathrm{M}+\mathrm{H}]^{+}$requires $m / z=374.1157$, found $m / z=374.1157$.

\subsubsection{Diethyl (4'-Cyano-5-Methyl-[1,1'-Biphenyl]-3-yl) Phosphonate (8b)}

The general procedure described above was followed using 4-bromobenzonitrile $(0.100 \mathrm{~g}, 0.551 \mathrm{mmol})$, precatalyst 6 (0.5 mol\%, $0.0015 \mathrm{~g}, 1.84 \mu \mathrm{mol}), \mathrm{K}_{3} \mathrm{PO}_{4}(0.17 \mathrm{~g}$, $0.734 \mathrm{mmol}), \mathbf{5 b}(0.131 \mathrm{~g}, 0.37 \mathrm{mmol})$, THF ( $4 \mathrm{~mL})$ and water $(2 \mathrm{~mL})$. The crude residue was purified by column chromatography (ethyl acetate: hexanes 2/1) to afford $\mathbf{8 b}$ as colourless oil in $34 \%$ yield $(0.041 \mathrm{~g}, 0.126 \mathrm{mmol}) .{ }^{1} \mathrm{H}$ NMR (300 MHz, $\left.\mathrm{CDCl}_{3}\right): \delta 7.75-7.71(\mathrm{~m}, 2 \mathrm{H}, \mathrm{Ar}-H)$, 7.71 (s, 1H, Ar-H), $7.66-7.56(\mathrm{~m}, 2 \mathrm{H}, \mathrm{Ar}-H), 7.37-7.35$ $(\mathrm{m}, 2 \mathrm{H}, \mathrm{Ar}-H), 7.67(\mathrm{dt}, J=7.8 \mathrm{~Hz}, 1 \mathrm{H}, \mathrm{Ar}-H), 7.60$ (d, $1 \mathrm{H}, \mathrm{Ar}-H), 7.43-7.41$ (m, 3H, Ar-H), 4.19-4.03 (m, 4H, $\left.-\mathrm{CH}_{2}\right), 2.41\left(\mathrm{~s}, 3 \mathrm{H}, \mathrm{Ar}-\mathrm{CH}_{3}\right), 2.32\left(\mathrm{~s}, 3 \mathrm{H},-\mathrm{CH}_{3}\right), 1.28(\mathrm{t}$, $\left.J=7.5 \mathrm{~Hz}, 6 \mathrm{H},-\mathrm{OCH}_{2} \mathrm{CH}_{3}\right) ;{ }^{31} \mathrm{P} \mathrm{NMR}\left(162 \mathrm{MHz}, \mathrm{CDCl}_{3}\right)$ : $\delta 18.4$ (s); IR (neat) $\left(\mathrm{cm}^{-1}\right): 2983.1,2256.6,1593.2,1154.7$, 990.6; $\mathrm{R}_{\mathrm{f}}$ (ethyl acetate: hexanes, $\left.2: 1\right)=0.33 ; \operatorname{HRMS}\left(\mathrm{ES}^{+}\right)$: exact mass calculated for $\mathrm{C}_{18} \mathrm{H}_{21} \mathrm{NO}_{3} \mathrm{P}[\mathrm{M}+\mathrm{H}]^{+}$requires $\mathrm{m} / \mathrm{z}=330.1259$, found $\mathrm{m} / \mathrm{z}=330.1269$.

\subsubsection{Diethyl (4'-Cyano-5-(Trifluoromethyl)-[1,1'-Biphenyl ]-3-yl)Phosphonate (8c)}

The general procedure described above was followed using 4-bromobenzonitrile $(0.100 \mathrm{~g}, 0.551 \mathrm{mmol})$, precatalyst 6 (0.5 mol\%, $0.0015 \mathrm{~g}, 1.84 \mu \mathrm{mol}), \mathrm{K}_{3} \mathrm{PO}_{4}(0.17 \mathrm{~g}$, $0.734 \mathrm{mmol}), 5 \mathrm{c}(0.151 \mathrm{~g}, 0.37 \mathrm{mmol})$, THF (4 mL) and water $(2 \mathrm{~mL})$. The crude residue was purified by column chromatography (ethyl acetate: hexanes, 2/1) to afford $\mathbf{8 c}$ as a colourless oil in $33 \%$ yield $(0.047 \mathrm{~g}, 0.122 \mathrm{mmol}) .{ }^{1} \mathrm{H}$ NMR $\left(300 \mathrm{MHz} \mathrm{CDCl}_{3}\right) \delta 8.15(\mathrm{~d}, 1 \mathrm{H}, J=12.0 \mathrm{~Hz}, \mathrm{Ar}-H), 8.02$ (d, $J=12.0 \mathrm{~Hz}, 1 \mathrm{H}, \mathrm{Ar}-H) 7.92$ (s, 1H, Ar-H), 7.75-7.72 $(\mathrm{m}, 2 \mathrm{H}, \mathrm{Ar}-H), 7.68-7.65(\mathrm{~m}, 2 \mathrm{H}, \mathrm{Ar}-H), 4.21-4.01(\mathrm{~m}$, $\left.4 \mathrm{H},-\mathrm{CH}_{2}\right), 1.30\left(\mathrm{t}, J=6.0 \mathrm{~Hz}, 6 \mathrm{H},-\mathrm{OCH}_{2} \mathrm{CH}_{3}\right) ;{ }^{13} \mathrm{C} \mathrm{NMR}$ $\left(75 \mathrm{MHz} \mathrm{CDCl}_{3}\right) \delta 142.9(\mathrm{~s}), 140.5(\mathrm{~d}, J=15.0 \mathrm{~Hz}), 133.7$ (d, $J=10.0 \mathrm{~Hz}), 136.9$ (s), 133.0 (s), 132.1 (s), 132.2-131.9 (m), $129.2(\mathrm{~s}), 128.9-128.6(\mathrm{~m}), 128.0(\mathrm{~s}), 127.8-127.5$ (m), $122.4(\mathrm{q}, J=272.0 \mathrm{~Hz}), 118.4(\mathrm{~s}), 62.8(\mathrm{~d}, J=6.0 \mathrm{~Hz})$, $25.8(\mathrm{~d}, J=6.0 \mathrm{~Hz}), 16.4(\mathrm{~d}, J=26.0 \mathrm{~Hz}) ;{ }^{31} \mathrm{P} \mathrm{NMR}$ $\left(162 \mathrm{MHz}, \mathrm{CDCl}_{3}\right) \delta 15.5$ (s); IR (neat) $\left(\mathrm{cm}^{-1}\right): 2984.4$, 2229.0, 1608.7, 1509.2, 1152.3, 994.2; $\mathrm{HRMS}\left(\mathrm{ES}^{+}\right)$: exact mass calculated for $\mathrm{C}_{18} \mathrm{H}_{18} \mathrm{NF}_{3} \mathrm{O}_{3} \mathrm{P}[\mathrm{M}+\mathrm{H}]^{+}$requires $\mathrm{m} / \mathrm{z}=384.0976$, found $\mathrm{m} / \mathrm{z}=384.0975$.

\subsubsection{Methyl 5-(Diethoxyphosphoryl)-2'-Me- thyl-[1,1'-Biphenyl]-3-Carboxylate (9a)}

The general procedure described above was followed using 2-bromotoluene $(0.094 \mathrm{~g}, 0.551 \mathrm{mmol})$, pre-catalyst $6(0.5 \mathrm{~mol} \%, 0.0015 \mathrm{~g}, 1.84 \mu \mathrm{mol}), \mathrm{K}_{3} \mathrm{PO}_{4}(0.17 \mathrm{~g}$, $0.734 \mathrm{mmol}), 5 \mathbf{a}(0.147 \mathrm{~g}, 0.37 \mathrm{mmol})$, THF $(4 \mathrm{~mL})$ and water $(2 \mathrm{~mL})$. The crude residue was purified by column chromatography (ethyl acetate: hexanes 2/1) to afford 9a as a white solid in $49 \%$ yield $(0.065 \mathrm{~g}, 0.181 \mathrm{mmol}) .{ }^{1} \mathrm{H}$ NMR (300 MHz, $\left.\mathrm{CDCl}_{3}\right): \delta 8.37(\mathrm{~d}, J=13.3 \mathrm{~Hz}, 1 \mathrm{H}, \mathrm{Ar}-H)$, $8.12(\mathrm{~s}, 1 \mathrm{H}, \mathrm{Ar}-H), 7.90(\mathrm{~d}, J=12.2 \mathrm{~Hz}, 1 \mathrm{H}, \mathrm{Ar}-H), 7.35$ - $6.96(\mathrm{~m}, 4 \mathrm{H}, \mathrm{Ar}-\mathrm{H}), 4.25-3.97$ (m, 4H, $\left.-\mathrm{CH}_{2} \mathrm{CH}_{3}\right), 3.87$ $\left(\mathrm{s}, 3 \mathrm{H},-\mathrm{OCH}_{3}\right), 2.18\left(\mathrm{~s}, 3 \mathrm{H},-\mathrm{CH}_{3}\right), 1.27(\mathrm{t}, J=7.64 \mathrm{~Hz}, 6 \mathrm{H}$, $\left.-\mathrm{OCH}_{2} \mathrm{CH}_{3}\right) ;{ }^{13} \mathrm{C} \mathrm{NMR}\left(75 \mathrm{MHz}, \mathrm{CDCl}_{3}\right): \delta 166.3$ (s), 142.8 (s), 139.8 (s), 136.6 (s), 135.3 (s), 134.1 (s), 131.3 (s), 130.6 (s), 129.9 (d, J=9.2 Hz), 129.2 (d, J=187.6 Hz), 128.9 (s), 126.2 (s) 125.7 (s), 62.6 (d, J=20.9 Hz), 52.6 (s), 20.5 (d, $J=8.5 \mathrm{~Hz}), 16.5(\mathrm{~d}, J=25.6 \mathrm{~Hz}) ;{ }^{31} \mathrm{P} \mathrm{NMR}(162 \mathrm{MHz}$, $\left.\mathrm{CDCl}_{3}\right): \delta 17.1$ (s) IR (neat) $\left(\mathrm{cm}^{-1}\right) ; 2983.1,1727.6,1593.2$, 1155.9, 988.3; $\mathrm{R}_{\mathrm{f}}$ (ethyl acetate: petrol, 2: 1) =0.30; Anal. calcd. for $\mathrm{C}_{19} \mathrm{H}_{23} \mathrm{O}_{5} \mathrm{P} ; \mathrm{C}, 62.98 ; \mathrm{H}, 6.40$. Found: $\mathrm{C}, 63.34$; $\mathrm{H}$ 6.97; HRMS $\left(\mathrm{ES}^{+}\right)$: exact mass calculated for $\mathrm{C}_{19} \mathrm{H}_{24} \mathrm{O}_{5} \mathrm{P}$ $[\mathrm{M}+\mathrm{H}]^{+}$requires $m / z=363.1361$, found $m / z=363.1366$.

\subsubsection{Diethyl (2',5-Dimethyl-[1,1'-Biphenyl]-3-yl)Phospho- nate $(9 b)$}

The general procedure described above was followed using 2-bromotoluene $(0.094 \mathrm{~g}, 0.551 \mathrm{mmol})$, pre-catalyst $6(0.5 \mathrm{~mol} \%, 0.0015 \mathrm{~g}, 1.84 \mu \mathrm{mol}), \mathrm{K}_{3} \mathrm{PO}_{4}(0.17 \mathrm{~g}$, $0.734 \mathrm{mmol}), 5 \mathbf{b}(0.131 \mathrm{~g}, 0.37 \mathrm{mmol})$, THF (4 mL) and water $(2 \mathrm{~mL})$. The crude residue was purified by column chromatography (ethyl acetate: hexanes 2/1) to afford $\mathbf{9 b}$ as a colourless oil in $37 \%$ yield $(0.044 \mathrm{~g}, 0.147 \mathrm{mmol})$. ${ }^{1} \mathrm{H} \mathrm{NMR}\left(300 \mathrm{MHz}, \mathrm{CDCl}_{3}\right): \delta 7.65$ (s, 1H, Ar-H), 7.69 (d, $J=7.8 \mathrm{~Hz}, 1 \mathrm{H}, \mathrm{Ar}-H), 7.53$ (s, $1 \mathrm{H}, \mathrm{Ar}-H), 7.32-7.21$ (m, 4H, Ar-H), 4.21-4.06 (m, 4H, $\left.-\mathrm{OCH}_{2} \mathrm{CH}_{3}\right), 2.44$ (s, $\left.3 \mathrm{H},-\mathrm{ArCH}_{3}\right), 2.25\left(\mathrm{~s}, 3 \mathrm{H},-\mathrm{CH}_{3}\right), 1.34(\mathrm{t}, J=7.1 \mathrm{~Hz}, 6 \mathrm{H}$, $-\mathrm{OCH}_{2} \mathrm{CH}_{3}$ ); ${ }^{13} \mathrm{C} \mathrm{NMR}\left(75 \mathrm{MHz}, \mathrm{CDCl}_{3}\right.$ ): $\delta 141.5$ (s), 140.0 $(\mathrm{d}, J=8.7 \mathrm{~Hz}), 137.3(\mathrm{~d}, J=8.9 \mathrm{~Hz}), 137.2(\mathrm{~d}, J=8.5 \mathrm{~Hz})$, 134.2 (s), 133.8 (d, J=8.4 Hz), 130.0 (s), 129.8 (s), 129.5 (d, $J=186.9 \mathrm{~Hz}), 128.9$ (d, $J=8.6 \mathrm{~Hz}), 125.9$ (s) 124.8 (s), 61.9 (d, $J=20.6 \mathrm{~Hz}$ ), 20.2 (s), 19.7 (d, $J=8.9 \mathrm{~Hz}), 16.6$ $(\mathrm{d}, J=25.1 \mathrm{~Hz}) ;{ }^{31} \mathrm{P}$ NMR $\left(162 \mathrm{MHz}, \mathrm{CDCl}_{3}\right): \delta 19.1(\mathrm{~s})$; IR (neat) $\left(\mathrm{cm}^{-1}\right): 2980.6,1595.7,1152.3,992.2 ; \mathrm{R}_{\mathrm{f}}$ (ethyl acetate: hexanes, $2: 1)=0.48 ; \operatorname{HRMS}\left(\mathrm{ES}^{+}\right)$: exact mass 
calculated for $\mathrm{C}_{18} \mathrm{H}_{23} \mathrm{O}_{3} \mathrm{P}[\mathrm{M}+\mathrm{H}]^{+}$requires $\mathrm{m} / z=319.1463$, found $m / z=319.1465$.

\subsubsection{Diethyl (2'-Methyl-5-(Trifluoromethyl)-[1,1'-Bipheny I]-3-yl)Phosphonate (9c)}

The general procedure described above was followed using 2-bromotoluene $(0.094 \mathrm{~g}, 0.551 \mathrm{mmol})$, pre-catalyst $6(0.5 \mathrm{~mol} \%, 0.0015 \mathrm{~g}, 1.84 \delta \mathrm{mol}), \mathrm{K}_{3} \mathrm{PO}_{4}(0.17 \mathrm{~g}$, $0.734 \mathrm{mmol}), \mathbf{5 c}(0.151 \mathrm{~g}, 0.37 \mathrm{mmol})$, THF (4 mL) and water $(2 \mathrm{~mL})$. The crude residue was purified by column chromatography (ethyl acetate: hexanes, 2/1) to afford 9c as an off-white solid in $35 \%$ yield $(0.048 \mathrm{~g}, 0.129 \mathrm{mmol})$. ${ }^{1} \mathrm{H}$ NMR $\left(300 \mathrm{MHz}, \mathrm{CDCl}_{3}\right): \delta 7.98(\mathrm{~d}, J=12.0 \mathrm{~Hz}, 1 \mathrm{H}$, $\mathrm{Ar}-H), 7.89$ (d, $J=12.0 \mathrm{~Hz}, 1 \mathrm{H}, \mathrm{Ar}-H) 7.71-7.68(\mathrm{~m}, 1 \mathrm{H}$, Ar-H), 7.44-7.41 (m, 2H, Ar-H), 7.22-7.17 (m, 5H, Ar-H), 4.23-3.99 (m, 4H, $\left.-\mathrm{OCH}_{2} \mathrm{CH}_{3}\right), 2.19\left(\mathrm{~s}, 3 \mathrm{H},-\mathrm{CH}_{3}\right), 1.29$ (t, $\left.J=6.0 \mathrm{~Hz}, 6 \mathrm{H},-\mathrm{OCH}_{2} \mathrm{CH}_{3}\right) ;{ }^{13} \mathrm{C} \mathrm{NMR}\left(75 \mathrm{MHz}, \mathrm{CDCl}_{3}\right)$ : $\delta 143.2(\mathrm{~d}, J=14.0 \mathrm{~Hz}), 139.2(\mathrm{~s}), 135.6(\mathrm{~d}, J=10.0 \mathrm{~Hz})$, $135.2(\mathrm{~s}), 133.0(\mathrm{~s}), 132.3-132.0(\mathrm{~m}), 131.3-131.0(\mathrm{~m})$, $130.7(\mathrm{~s}), 130.6(\mathrm{~s}), 129.8-129.6(\mathrm{~m}), 129.5(\mathrm{~s}), 128.4(\mathrm{~s})$, $126.9-126.7(\mathrm{~m}), 126.2(\mathrm{~s}), 123.6(\mathrm{q}, J=272.0 \mathrm{~Hz}), 62.6$ (d, $J=6.0 \mathrm{~Hz}), 20.3(\mathrm{~s}), 16.4(\mathrm{~d}, J=6.0 \mathrm{~Hz}) ;{ }^{31} \mathrm{P}$ NMR $\left(162 \mathrm{MHz}, \mathrm{CDCl}_{3}\right): \delta 16.3$ (s); IR (neat) $\left(\mathrm{cm}^{-1}\right): 2963.2$, 1602.4, 1149.3, 996.1; HRMS (ES $\left.{ }^{+}\right)$: exact mass calculated for $\mathrm{C}_{18} \mathrm{H}_{21} \mathrm{~F}_{3} \mathrm{O}_{3} \mathrm{P}[\mathrm{M}+\mathrm{H}]^{+}$requires $m / z=373.1179$, found $\mathrm{m} / \mathrm{z}=373.1180$.

\subsubsection{Methyl 3-(Diethoxyphosphoryl)-5-(Naphthalen-1-yl) Benzoate (10a)}

The general procedure described above was followed using 1-bromonaphthalene $(0.114 \mathrm{~g}, 0.551 \mathrm{mmol})$, precatalyst $6(0.5 \mathrm{~mol} \%, 0.0015 \mathrm{~g}, 1.84 \mu \mathrm{mol}), \mathrm{K}_{3} \mathrm{PO}_{4}(0.17 \mathrm{~g}$, $0.734 \mathrm{mmol}), \mathbf{5 a}(0.147 \mathrm{~g}, 0.37 \mathrm{mmol})$, THF (4 mL) and water $(2 \mathrm{~mL})$. The crude residue was purified by column chromatography (ethyl acetate: hexanes $2 / 1$ ) to afford 10a as an off-white solid in $49 \%$ yield $(0.072 \mathrm{~g}, 0.181 \mathrm{mmol})$. ${ }^{1} \mathrm{H} \mathrm{NMR}\left(300 \mathrm{MHz}, \mathrm{CDCl}_{3}\right): \delta 8.56(\mathrm{dt}, J=14.0 \mathrm{~Hz}, 1 \mathrm{H}$, $\mathrm{Ar}-H), 8.37$ (s, $1 \mathrm{H}, \mathrm{Ar}-H), 8.14(\mathrm{dt}, J=13.2 \mathrm{~Hz}, 1 \mathrm{H}, \mathrm{Ar}-H$ ), $7.2(\mathrm{t}, J=5.4 \mathrm{~Hz}, 1 \mathrm{H}, \mathrm{Ar}-H), 7.75(\mathrm{~d}, 1 \mathrm{H}, \mathrm{Ar}-H), 7.57-7.42$ $(\mathrm{m}, 5 \mathrm{H}, \mathrm{Ar}-\mathrm{H}), 4.25-4.04\left(\mathrm{~m}, 4 \mathrm{H},-\mathrm{OCH}_{2} \mathrm{CH}_{3}\right), 3.96$ (s, $\left.3 \mathrm{H},-\mathrm{OCH}_{3}\right), 2.41\left(\mathrm{~s}, 3 \mathrm{H},-\mathrm{CH}_{3}\right), 1.35(\mathrm{t}, J=7.8 \mathrm{~Hz}, 6 \mathrm{H}$, $\left.-\mathrm{OCH}_{2} \mathrm{CH}_{3}\right) ;{ }^{13} \mathrm{C} \mathrm{NMR}\left(75 \mathrm{MHz}, \mathrm{CDCl}_{3}\right.$ ): $\delta 166.3(\mathrm{~s}), 141.7$ (d, $J=8.7 \mathrm{~Hz}), 137.9$ (s), 137.4 (s), 137.3 (s), 135.0 (s), 133.2 (s), $131.8(\mathrm{~s}), 131.3(\mathrm{~d}, J=9.1 \mathrm{~Hz}), 130.9(\mathrm{~d}, J=187.6 \mathrm{~Hz})$, 130.8 (s), 130.3 (s) 129.2 (s), 128.7 (d, $J=9.2 \mathrm{~Hz}), 127.5$ (s), $126.5(\mathrm{~d}, J=15.2 \mathrm{~Hz}), 125.4(\mathrm{~d}, J=8.9 \mathrm{~Hz}), 62.7(\mathrm{~d}$, $J=20.6 \mathrm{~Hz}), 52.6(\mathrm{~s}), 16.6(\mathrm{~d}, J=26.0 \mathrm{~Hz}) ;{ }^{31} \mathrm{P} \mathrm{NMR}$ $\left(162 \mathrm{MHz}, \mathrm{CDCl}_{3}\right): \delta 17.0$ (s); IR (neat) $\left(\mathrm{cm}^{-1}\right): 2982.9$, 1725.3, 1592.1, 1152.7, 991.0; $\mathrm{R}_{\mathrm{f}}$ (ethyl acetate: hexanes, 2: 1) $=0.27$; Anal. calcd. for $\mathrm{C}_{22} \mathrm{H}_{23} \mathrm{O}_{5} \mathrm{P} ; \mathrm{C}, 66.33 ; \mathrm{H}$, 5.82. Found: C, 66.61; H 6.06; HRMS $\left(\mathrm{ES}^{+}\right)$: exact mass calculated for $\mathrm{C}_{22} \mathrm{H}_{24} \mathrm{O}_{5} \mathrm{P}[\mathrm{M}+\mathrm{H}]^{+}$requires $m / z=399.1361$, found $m / z=399.1362$.

\subsubsection{Diethyl (3-Methyl-5-(Naphthalen-1-yl)Phenyl)Phos- phonate (10b)}

The general procedure described above was followed using 1-bromonaphthalene $(0.114 \mathrm{~g}, 0.551 \mathrm{mmol})$, precatalyst $6(0.5 \mathrm{~mol} \%, 0.0015 \mathrm{~g}, 1.84 \mu \mathrm{mol}), \mathrm{K}_{3} \mathrm{PO}_{4}(0.17 \mathrm{~g}$, $0.734 \mathrm{mmol}), \mathbf{5 b}(0.131 \mathrm{~g}, 0.37 \mathrm{mmol})$, THF $(4 \mathrm{~mL})$ and water $(2 \mathrm{~mL})$. The crude residue was purified by column chromatography (ethyl acetate: hexanes, 2/1) to afford 10b as an off-white solid in $39 \%$ yield $(0.051 \mathrm{~g}, 0.144 \mathrm{mmol}) .{ }^{1} \mathrm{H}$ NMR (300 MHz, $\left.\mathrm{CDCl}_{3}\right)$ : $\delta 7.92(\mathrm{~d}, J=7.9 \mathrm{~Hz}, 1 \mathrm{H}, \mathrm{Ar}-H)$, $7.86(\mathrm{~s}, 1 \mathrm{H}, \mathrm{Ar}-H), 7.82(\mathrm{~d}, J=8.1 \mathrm{~Hz}, 1 \mathrm{H}, \mathrm{Ar}-H), 7.72$ $(\mathrm{m}, 2 \mathrm{H}, \mathrm{Ar}-H), 7.55-7.39$ (m, 5H, Ar-H), $4.23-4.04(\mathrm{~m}$, $\left.4 \mathrm{H},-\mathrm{OCH}_{2} \mathrm{CH}_{3}\right), 2.48$ (s, 3H, Ar- $\left.\mathrm{CH}_{3}\right), 1.35$ (t, $J=7.1 \mathrm{~Hz}$, $\left.6 \mathrm{H},-\mathrm{OCH}_{2} \mathrm{CH}_{3}\right) ;{ }^{13} \mathrm{C}$ NMR $\left(75 \mathrm{MHz}, \mathrm{CDCl}_{3}\right): \delta 141.7(\mathrm{~d}$, $J=8.7 \mathrm{~Hz}$ ), 137.9 (s), 137.4 (s), 135.0 (s), 134.5 (s), 133.2 (s), $131.8(\mathrm{~s}), 131.2(\mathrm{~d}, J=9.1 \mathrm{~Hz}), 130.8(\mathrm{~d}, J=187.6 \mathrm{~Hz})$, 130.5 (s), 130.3 (s) 129.2 (s), 128.7 (d, $J=9.2 \mathrm{~Hz}), 127.5$ (s), $126.5(\mathrm{~d}, J=15.2 \mathrm{~Hz}), 125.4(\mathrm{~d}, J=8.9 \mathrm{~Hz}), 62.7(\mathrm{~d}$, $J=20.6 \mathrm{~Hz}), 21.7(\mathrm{~s}), 16.6(\mathrm{~d}, J=26.0 \mathrm{~Hz}) ;{ }^{31} \mathrm{P}$ NMR $\left(162 \mathrm{MHz}, \mathrm{CDCl}_{3}\right): \delta 19.1$; (s) IR (neat) $\left(\mathrm{cm}^{-1}\right): 2982.0$, 1592.8, 1149.7, 990.7; $\mathrm{R}_{\mathrm{f}}$ (ethyl acetate: hexanes, 2: 1) $=0.40$; Anal. calcd. for $\mathrm{C}_{21} \mathrm{H}_{23} \mathrm{O}_{3} \mathrm{P} ; \mathrm{C}, 71.17 ; \mathrm{H}, 6.54$. Found: C, 71.57; H 6.97; HRMS (ES ${ }^{+}$): exact mass calculated for $\mathrm{C}_{21} \mathrm{H}_{24} \mathrm{O}_{3} \mathrm{P}[\mathrm{M}+\mathrm{H}]^{+}$requires $\mathrm{m} / \mathrm{z}=355.1463$, found $m / z=355.1463$.

\subsubsection{Diethyl (3-Trifluoromethyl-5-(Naphthalen-1-yl) Phenyl)Phosphonate (10c)}

The general procedure described above was followed using 1-bromonaphthalene $(0.114 \mathrm{~g}, 0.551 \mathrm{mmol})$, precatalyst $6(0.5 \mathrm{~mol} \%, 0.0015 \mathrm{~g}, 1.84 \mu \mathrm{mol}), \mathrm{K}_{3} \mathrm{PO}_{4}(0.17 \mathrm{~g}$, $0.734 \mathrm{mmol}), \mathbf{5 c}(0.151 \mathrm{~g}, 0.37 \mathrm{mmol})$, THF (4 mL) and water $(2 \mathrm{~mL})$. The crude residue was purified by column chromatography (ethyl acetate: hexanes, 2/1) to afford 10c as an off-white solid in $35 \%$ yield $(0.053 \mathrm{~g}, 0.130 \mathrm{mmol}) .{ }^{1} \mathrm{H}$ NMR (300 MHz, $\left.\mathrm{CDCl}_{3}\right): \delta 8.05(\mathrm{~d}, J=7.8 \mathrm{~Hz}, 1 \mathrm{H}, \mathrm{Ar}-H$ ), $7.94(\mathrm{~s}, 1 \mathrm{H}, \mathrm{Ar}-H), 7.82(\mathrm{~d}, J=8.1 \mathrm{~Hz}, 1 \mathrm{H}, \mathrm{Ar}-H), 7.74$ $(\mathrm{m}, 2 \mathrm{H}, \mathrm{Ar}-H), 7.55-7.39(\mathrm{~m}, 5 \mathrm{H}, \mathrm{Ar}-H), 4.21-4.04(\mathrm{~m}$, $\left.4 \mathrm{H},-\mathrm{OCH}_{2} \mathrm{CH}_{3}\right), 1.31\left(\mathrm{t}, J=7.1 \mathrm{~Hz}, 6 \mathrm{H},-\mathrm{OCH}_{2} \mathrm{CH}_{3}\right) ;{ }^{13} \mathrm{C}$ NMR (75 MHz, $\left.\mathrm{CDCl}_{3}\right): \delta 140.9(\mathrm{~d}, J=8.4 \mathrm{~Hz}), 138.1(\mathrm{~s})$, 137.5 (s), 135.0 (s), 134.6 (s), 133.7 (s), 131.8 (s), 131.4 (d, $J=9.1 \mathrm{~Hz}), 130.8(\mathrm{~d}, J=187.6 \mathrm{~Hz}), 130.6(\mathrm{~s}), 130.3$ (s) $129.4(\mathrm{~s}), 128.7(\mathrm{~d}, J=9.2 \mathrm{~Hz}), 127.7(\mathrm{~s}), 127.1(\mathrm{~d}$, $J=15.2 \mathrm{~Hz}), 125.1(\mathrm{~d}, J=8.9 \mathrm{~Hz}), 122.4(\mathrm{q}, J=274 \mathrm{~Hz})$, $62.4(\mathrm{~d}, J=20.6 \mathrm{~Hz}), 16.9(\mathrm{~d}, J=26.0 \mathrm{~Hz}) ;{ }^{31} \mathrm{P} \mathrm{NMR}$ $\left(162 \mathrm{MHz}, \mathrm{CDCl}_{3}\right.$ ): $\delta 16.1$; (s); $\mathrm{R}_{\mathrm{f}}$ (ethyl acetate: hexanes, 2: 1) $=0.33$; HRMS $\left(\mathrm{ES}^{+}\right)$: exact mass calculated 
for $\mathrm{C}_{21} \mathrm{H}_{21} \mathrm{~F}_{3} \mathrm{O}_{3} \mathrm{P}[\mathrm{M}+\mathrm{H}]^{+}$requires $m / z=409.1180$, found $\mathrm{m} / \mathrm{z}=409.1183$.

\subsubsection{Methyl 5-(Diethoxyphosphoryl)-4'-Me- thyl-[1,1'-Biphenyl]-3-Carboxylate (11a)}

The general procedure described above was followed using 4-bromotoluene $(0.100 \mathrm{~g}, 0.551 \mathrm{mmol})$, pre-catalyst $6(0.5 \mathrm{~mol} \%, 0.0015 \mathrm{~g}, 1.84 \mu \mathrm{mol}), \mathrm{K}_{3} \mathrm{PO}_{4}(0.17 \mathrm{~g}$, $0.734 \mathrm{mmol}), \mathbf{5 a}(0.147 \mathrm{~g}, 0.37 \mathrm{mmol})$, THF $(4 \mathrm{~mL})$ and water $(2 \mathrm{~mL})$. The crude residue was purified by column chromatography (ethyl acetate: hexanes 2/1) to afford 11a as a colourless oil in $47 \%$ yield $(0.063 \mathrm{~g}, 0.173 \mathrm{mmol}) .{ }^{1} \mathrm{H}$ $\operatorname{NMR}\left(300 \mathrm{MHz}, \mathrm{CDCl}_{3}\right): \delta 8.33(\mathrm{dt}, J=15.8 \mathrm{~Hz}, 2 \mathrm{H}, \mathrm{Ar}-H)$, $8.15(\mathrm{dt}, J=13.6 \mathrm{~Hz}, 1 \mathrm{H}, \mathrm{Ar}-H), 7.35(\mathrm{dd}, J=8.0 \mathrm{~Hz}$, $8.7 \mathrm{~Hz}, 4 \mathrm{H}, \mathrm{Ar}-\mathrm{H}$ ), 4.25-4.04 (m, $\left.4 \mathrm{H},-\mathrm{OCH}_{2} \mathrm{CH}_{3}\right), 3.96$ (s, $\left.3 \mathrm{H},-\mathrm{OCH}_{3}\right), 2.41\left(\mathrm{~s}, 3 \mathrm{H},-\mathrm{CH}_{3}\right), 1.35(\mathrm{t}, J=7.24 \mathrm{~Hz}, 6 \mathrm{H}$, $\left.-\mathrm{OCH}_{2} \mathrm{CH}_{3}\right) ;{ }^{13} \mathrm{C} \mathrm{NMR}\left(75 \mathrm{MHz}, \mathrm{CDCl}_{3}\right): \delta 166.4(\mathrm{~s}), 142.1$ (d, $J=8.6 \mathrm{~Hz}), 138.5(\mathrm{~s}), 136.2(\mathrm{~s}), 134.4(\mathrm{~d}, J=8.6 \mathrm{~Hz})$, 131.8 (s), 131.7 (s), 131.2 (d, $J=9.1 \mathrm{~Hz}), 131.1$ (s), 130.7 $(\mathrm{d}, J=187.6 \mathrm{~Hz}), 130.5(\mathrm{~s}), 130.0(\mathrm{~d}, J=9.0 \mathrm{~Hz}), 127.2(\mathrm{~s})$, $62.6(\mathrm{~d}, J=20.6 \mathrm{~Hz}), 52.6(\mathrm{~s}), 21.3(\mathrm{~d}, J=8.7 \mathrm{~Hz}), 16.5$ $(\mathrm{d}, J=25.8 \mathrm{~Hz}) ;{ }^{31} \mathrm{P}$ NMR $\left(162 \mathrm{MHz}, \mathrm{CDCl}_{3}\right): \delta 17.3(\mathrm{~s})$; IR (neat) $\left(\mathrm{cm}^{-1}\right)$ : 2983.1, 1727.6, 1593.2, 1154.6, 993.4; $\mathrm{R}_{\mathrm{f}}$ (ethyl acetate: hexanes, 2: 1) $=0.47$; $\mathrm{HRMS}\left(\mathrm{ES}^{+}\right)$: exact mass calculated for $\mathrm{C}_{19} \mathrm{H}_{23} \mathrm{O}_{5} \mathrm{P}[\mathrm{M}+\mathrm{Na}]^{+}$requires $m / z=385.1181$, found $m / z=385.1182$.

\subsubsection{Diethyl (4',5-dimethyl-[1,1'-biphenyl]-3-yl)phospho- nate (11b)}

The general procedure described above was followed using 4-bromotoluene $(0.094 \mathrm{~g}, 0.551 \mathrm{mmol})$, pre-catalyst $6(0.5 \mathrm{~mol} \%, 0.0015 \mathrm{~g}, 1.84 \mu \mathrm{mol}), \mathrm{K}_{3} \mathrm{PO}_{4}(0.17 \mathrm{~g}$, $0.734 \mathrm{mmol}), \mathbf{5 b}(0.131 \mathrm{~g}, 0.37 \mathrm{mmol})$, THF (4 mL) and water $(2 \mathrm{~mL})$. The crude residue was purified by column chromatography (ethyl acetate: hexanes, 2/1) to afford 11b as a colourless oil in $39 \%$ yield $(0.046 \mathrm{~g}, 0.144 \mathrm{mmol}) .{ }^{1} \mathrm{H}$ $\operatorname{NMR}\left(300 \mathrm{MHz}, \mathrm{CDCl}_{3}\right): \delta 7.74(\mathrm{~d}, J=7.7 \mathrm{~Hz}, 1 \mathrm{H}, \mathrm{Ar}-H)$, 7.54 (s, $1 \mathrm{H}, \operatorname{Ar}-H), 7.49$ (s, $1 \mathrm{H}, \mathrm{Ar}-H), 7.30$ (m, 4H, Ar-H), 4.15-3.99 (m, 4H, $\left.-\mathrm{OCH}_{2} \mathrm{CH}_{3}\right), 2.38\left(\mathrm{~s}, 3 \mathrm{H},-\mathrm{CH}_{3}\right), 2.33$ (s, $\left.3 \mathrm{H},-\mathrm{CH}_{3}\right), 1.27\left(\mathrm{t}, J=7.5 \mathrm{~Hz}, 6 \mathrm{H},-\mathrm{OCH}_{2} \mathrm{CH}_{3}\right) ;{ }^{13} \mathrm{C} \mathrm{NMR}$ $\left(75 \mathrm{MHz}, \mathrm{CDCl}_{3}\right): \delta 140.7(\mathrm{~d}, J=8.6 \mathrm{~Hz}), 138.2(\mathrm{~s}), 137.1$ (s), $136.8(\mathrm{~s}), 131.2(\mathrm{~d}, J=9.0 \mathrm{~Hz}), 130.8(\mathrm{~d}, J=187.6 \mathrm{~Hz})$, $130.1(\mathrm{~d}, J=8.7 \mathrm{~Hz}), 128.1(\mathrm{~s}), 127.9(\mathrm{~s}), 127.2(\mathrm{~s}), 126.9$ (d, $J=9.1 \mathrm{~Hz}), 126.3(\mathrm{~s}), 62.2(\mathrm{~d}, J=20.7 \mathrm{~Hz}), 20.6(\mathrm{~s}), 20.3$ $(\mathrm{d}, J=8.6 \mathrm{~Hz}), 16.6(\mathrm{~d}, J=25.7 \mathrm{~Hz}) ;{ }^{31} \mathrm{P}$ NMR $(162 \mathrm{MHz}$, $\left.\mathrm{CDCl}_{3}\right): \delta 19.1(\mathrm{~s}) ; \mathrm{IR}$ (neat) $\left(\mathrm{cm}^{-1}\right): 2981.2,1597.3,1153.7$, 993.4; $\mathrm{R}_{\mathrm{f}}$ (ethyl acetate: hexanes, $\left.2: 1\right)=0.45 ; \mathrm{HRMS}\left(\mathrm{ES}^{+}\right)$: exact mass calculated for $\mathrm{C}_{18} \mathrm{H}_{24} \mathrm{O}_{3} \mathrm{P}[\mathrm{M}+\mathrm{H}]^{+}$requires $\mathrm{m} / \mathrm{z}=319.1463$, found $\mathrm{m} / \mathrm{z}=319.1463$.
Acknowledgements This study was funded by Newcastle University (D.O.P). We also gratefully acknowledge Taibah University, Saudi Arabia for a scholarship to H.Y.A. High resolution mass spectra were obtained at the ESPRC National Mass Spectrometry Service in Swansea. This article is dedicated to the memory of Elwood and Jake, may they rest in peace.

Open Access This article is licensed under a Creative Commons Attribution 4.0 International License, which permits use, sharing, adaptation, distribution and reproduction in any medium or format, as long as you give appropriate credit to the original author(s) and the source, provide a link to the Creative Commons licence, and indicate if changes were made. The images or other third party material in this article are included in the article's Creative Commons licence, unless indicated otherwise in a credit line to the material. If material is not included in the article's Creative Commons licence and your intended use is not permitted by statutory regulation or exceeds the permitted use, you will need to obtain permission directly from the copyright holder. To view a copy of this licence, visit http://creativecommons.org/licenses/by/4.0/.

\section{References}

1. Veale CA, Damewood JR, Steelman GB, Bryant C, Gomes B, Williams J (1995) J Med Chem 38:86

2. Ortwine DF, Malone TC, Bigge CF, Drummond JT, Humblet C, Johnson G, Pinter GW (1992) J Med Chem 35:1345

3. Huang WS, Liu S, Zou D, Thomas M, Wang Y, Zhou T, Romero J, Kohlmann A, Li, F, Qi J, Cai L, Dwight TA, Xu Y, Xu R, Dodd R, Toms A, Parillon L, Lu X, Anjum R, Zhang S, Wang F, Keats J, Wardwell SD, Ning Y, Xu Q, Moran LE, Mohemmad QK, Jang HG, Clackson T, Narasimhan NI, Rivera VM, Zhu X, Dalgarno D, Shakespeare WC (2106) J Med Chem 59: 4948

4. Dang Q, Liu Y, Cashion DK, Kasibhatla J Sr, Jiang T, Taplin F, Jacintho JD, Li H, Sun Z, Fan Y, DaRe J, Tian F, Li W, Gibson T, Lemus R, van Poelje PD, Potter SC, Erion MD (2011) J Med Chem 54:153

5. Lassaux P, Hamel M, Gulea M, Delbrück HE, Mercuri PS, Horsfall L, Dehareng D, Kupper M, Frère JM, Hoffmann K, Galleni M, Bebrone C (2009) J Med Chem 54:4862

6. Chen XD, Kopecky DJ, Mihalic J, Jeffries S, Min X, Heath J, Deignan J, Lai S, Fu Z, Guimaraes C, She S, Li S, Johnstone S, Thibault S, Xu H, Cardozo M, Shen W, Walker N, Kayser F, Wang Z (2102) J Med Chem 55: 3837

7. Wydysh EA, Medghalchi SM, Vadlamudi A, Townsend CA (2009) J Med Chem 53:3317

8. P.J. Kamer, P.W.N.M. van Leeuwen Phosphorus (III) Ligands in Homogeneous Catalysis, Design and Synthesis (Wiley-VCH: New York, 2012).

9. Allcock HR, Hofmann MA, Ambler CM, Morford RV (2002) Macromolecules 35:3484

10. Queffélec C, Petit M, Janvier P, Knight DA, Bujoli B (2012) Chem Rev 112:3777

11. Troev KD (2006) Chemistry and Applications of H-Phosphonates. Elsevier, Amsterdam

12. Chou HH, Cheng CH (2010) Adv Mater 22:2468

13. Hsu FM, Chien $\mathrm{CH}$, Shu CF, Lai $\mathrm{CH}$, Hsieh CC, Wang KW, Chou PT (2009) Adv Funct Mater 19:2834

14. Gelman D, Jiang L, Buchwald SL (2003) Org Lett 5:2315

15. Hirao T, Masunaga T, Ohshiro Y, Agawa T (1980) Tetrahedron Lett 21:3595 
16. Hirao T, Masunaga T, Yamada N, Ohshiro Y, Agawa T (1982) Bull Chem Soc Jpn 55:900

17. Montchamp JL, Dumond YR (2001) J Am Chem Soc 123:510

18. Peng H, Cai R, Xu C, Chen H, Shi X (2016) Chem Sci 7:6190

19. Kalek M, Ziadi A, Stawinski J (2008) Org Lett 10:4637

20. Deal EL, Petit C, Montchamp JL (2011) Org Lett 13:3270

21. Fu WC, So CM, Kwong FY (2015) Org Lett 17:5906

22. Xu K, Yang F, Zhang G, Wu Y (2013) Green Chem 15:1055

23. Bloomfield AJ, Herzon SB (2012) Org Lett 14:4370

24. Łastawiecka E, Flis A, Stankevič M, Greluk M, Słowik G, Gac W (2018) Org Chem Frontiers 5:2079

25. Ramírez-López P, Ros A, Estepa B, Fernández R, Fiser B, Gómez-Bengoa E, Lassaletta JM (2016) ACS Catal 6:3955

26. Bonnaventure I, Charette AB (2008) J Org Chem 73:6330

27. Zhuang R, Xu J, Cai Z, Tang G, Fang M, Zhao Y (2011) Org Lett 13:2110

28. Hu G, Chen W, Fu T, Peng Z, Qiao H, Gao Y, Zhao Y (2013) Org Lett 15:5362

29. Chen TH, Reddy DM, Lee CF (2017) RSC Adv 7:30214

30. Andaloussi M, Lindh J, Sävmarker J, Sjöberg PJR, Larhed M (2009) Chem Eur J 15:13069

31. Fu T, Qiao H, Peng Z, Hu G, Wu X, Gao Y, Zhao Y (2014) Org Biomol Chem 12:2895

32. Luo H, Liu H, Chen X, Wang K, Luo X, Wang K (2017) Chem Commun 53:956

33. Geng Z, Zhang Y, Zheng L, Li J, Zou D, Wu Y, Wu Y (2016) Tetrahedron Lett 57:3063

34. Zeng H, Dou Q, Li CJ (2019) Org Lett 21:1301

35. Yuan J, To WP, Zhang ZY, Yue CD, Meng S, Chen J, Liu Y, Yu GA, Che CM (2018) Org Lett 20:7816

36. Isshiki R, Muto K, Yamaguchi J (2018) Org Lett 20:1150

37. Dong J, Liu L, Ji X, Shang Q, Liu L, Su L, Chen B, Kan R, Zhou Y, Yin SF, Han LB (2019) Org Lett 21:3198

38. Liu C, Szostak M (2017) Angew Chem Int Ed 56:12718

39. Xu JJ, Zhang P, Gao Y, Chen Y, Tang G, Zhao Y (2013) J Org Chem 78:8176

40. Feng CG, Ye M, Xiao KJ, Li S, Yu JQ (2013) J Am Chem Soc 135:9322

41. Hou C, Ren Y, Lang R, Hu X, Xia C, Li F (2012) Chem Commun 48:5181

42. Khrizanforov M, Strekalova S, Khrizanforova V, Dobrynin A, Kholin K, Gryaznova T, Grinenko V, Gubaidullin A, Kadirov MK, Budnikova Y (2018) Topics in Catal 61:1949

43. Shaikh RS, Ghosh I, König B (2017) Chem Eur J 50:12120

44. Hu RB, Wang HL, Zhang HY, Zhang H, Ma YN, Yang SD (2014) Bilstein J Org Chem 10:2071-2076

45. Wang S, Guo R, Wang G, Chen SY, Yu XQ (2014) Chem Commun 50:12718

46. Li C, Yano T, Ishida N, Murakami M (2013) Angew Chem Int Ed 52:9801

47. Xie P, Wang J, Fan J, Liu Y, Wo X, Loh TP (2017) Green Chem 19:1235-2139

48. Dhokale RA, Mhaske SB (2013) Org Lett 15:2218

49. Zhang Z, Dixneuf PH, Soule J-F (2018) For a highly insightful review on late-stage modifications of P-containing ligands using transition-metal-catalyzed $\mathrm{C}-\mathrm{H}$ bond functionalization see. Chem Commun 54:7265

50. Zhang H, Hu RB, Zhang XY, Li SX, Yang SD (2014) Chem Commun 50:4686

51. Zhao D, Nimphius C, Lindale M, Glorius F (2013) Org Lett 15:4504

52. Kuninobu Y, Yoshida T, Takai K (2011) J Org Chem 76:7370

53. Ma YN, Zhang HY, Yang SD (2015) Org Lett 17:2034

54. Hu RB, Zhang H, Zhang XY, Yang SD (2014) Chem Commun $50: 2193$
55. Zhang HY, Yi HM, Wang GW, Yang B, Yang SD (2013) Org Lett 15:6186

56. Yuan J, Yue CD, Zhang ZY, Chen J, Yu GA, Che CM (2018) Org Lett 20:1810

57. Li SX, Ma YN, Yang SD (2017) Org Lett 19:1842

58. Yin J, Buchwald SL (2000) J Am Chem Soc 122:12051

59. Shen X, Jones GO, Watson DA, Bhayana B, Buchwald SL (2010) J Am Chem Soc 132:11278

60. Tang W, Patel ND, Xu G, Xu X, Savoie J, Ma S, Hao MH, Keshipeddy S, Capacci AG, Wei X, Zhang Y, Gao JJ, Li W, Rodriguez S, Lu BZ, Yee NK, Senanayake CH (2012) Org Lett 14:2258

61. Wu W, Wang S, Zhou Y, Yue YH, Lanning Z, Wan LP, Wang L, Zhou Z, Qiu L (2012) Adv Synth Catal 354:2395

62. Yamamoto T, Akai Y, Nagata Y, Suginome M (2011) Angew Chem Int Ed 50:8844

63. Wang S, Li J, Miao T, Wu W, Li Q, Zhuang Y, Zhou Z, Qiu L (2012) Org Lett 14:1966

64. Zhou Y, Wang S, Wu W, Li Q, He Y, Zhuang Y, Li L, Pang J, Zhou Z, Qiu L (2013) Org Lett 15(15):5508

65. Zhou Y, Zhang X, Liang H, Cao Z, Zhao X, He Y, Wang S, Pang J, Zhou Z, Ke Z, Qiu L (2014) ACS Catal 4:1390

66. Zhang Y, Li Y, Pan B, Xu H, Liang H, Jiang X, Liu B, Tse MK, Qiu L (2019) Chemistry Select 4:5122

67. Ma YN, Yang SD (2016) Chem Record 16:977

68. D.G. Hall, Boronic Acids (Wiley-VCH; Weinheim, 2011).

69. Doherty S, Knight JG, Ward NAB, Perry DO, Bittner DM, Probert MR, Westcott SA (2014) Organometallics 33:5209

70. Xu F, Duke OM, Rojas D, Eichelberger HM, Kim RS, Clark TB, Watson DA (2020) J Am Chem Soc 142:11988

71. Wen J, Wang D, Qian J, Wang D, Zhu C, Zhao Y, Shi Z (2019) Angew Chem Int Ed 58:2078

72. Qiu X, Wang M, Zhao Y, Shi Z (2017) Angew Chem Int Ed 56:7233

73. Qiu X, Wang M, Zhao Y, Shi Z (2019) Angew Chem Int Ed 58:2850

74. Crawford KM, Ramseyer TR, Daley CJA, Clark TB (2014) Angew Chem Int Ed 53:7589

75. Wright SE, Richardson-Solorzano S, Stewart TN, Miller CD, Morris KC, Daley CJA, Clark TB (2019) Angew Chem Int Ed 58:2834

76. Luo X, Yuan J, Yue CD, Zhang ZY, Chen J, Yu GA, Che CM (2018) Org Lett 20:1810

77. Ishiyama T, Takagi J, Sihida K, Miyaura N, Anastasi NR, Hartwig JF (2002) J Am Chem Soc 124:390

78. Ishiyama T, Takagi J, Hartwig JF, Miyaura N (2002) Angew Chem Int Ed 41:3056

79. Cho JY, Tse MK, Holmes D, Maleczka RE, Smith MR (2002) Science 295:305

80. Maleczka RE, Shi F, Holmes D, Smith MR (2002) J Am Chem Soc 125: 7792.

81. Holmes D, Chotana GA, Maleczka RE, Smith MR (2006) Org Lett 8:1407

82. Tzschucke CC, Murphy JM, Hartwig JF (2007) Org Lett 9:761

83. Murphy JM, Tzschucke CC, Hartwig JF (2007) Org Lett 9:757

84. Murphy JM, Liao X, Hartwig JF (2007) J Am Chem Soc 129:15434

85. Liskey CW, Liao X, Hartwig JF (2010) J Am Chem Soc 132:11389

86. Robbins DW, Hartwig JF (2013) Angew Chem Int Ed 125:967

87. Joliton A, Carreira EM (2013) Org Lett 15:5147

88. Li X, Deng X, Coyne AG, Srinivasan R (2019) Chem Eur J 25:8018

89. Feng Z, Min QQ, Fu XP, An L, Zhang X (2017) Nature Chem 9:918

90. Litvinas ND, Fier PS, Hartwig JF (2012) Angew Chem Int Ed $51: 536$ 
91. Liu T, Shao X, Wu Y, Shen Q (2012) Angew Chem Int Ed 51:540

92. Chotana GA, Bastidas JRM, Miller SL, Smith MR, Maleczka RE (2020) Molecules 25: 1754.

93. Wang J, Torigoe T, Kuninobu Y (2019) Org Lett 21:1342

94. Kuninobu Y, Ida H, Nishi M, Kanai M (2015) Nature Chem 7:712

95. Davis HJ, Mihai MT, Phipps RJ (2016) J Am Chem Soc 138:12759

96. Bisht R, Chattopadhyay B (2016) J Am Chem Soc 138:84

97. Yang L, Uemura N, Nakao Y (2019) J Am Chem Soc 141:7972

98. Gao P, Szostak M (2020) Org Lett 22:6010

99. Mkhalid IAI, Barnard JH, Marder TB, Murphy JM, Hartwig JF (2010) Chem Rev 110:890

100. Hartwig JF (2012) Acc Chem Res 45:864

101. Preshlock SM, Ghaffari B, Maligres PE, Krska SW, Maleczka RE, Smith MR (2013) J Am Chem Soc 125:7572

102. Liskey CW, Hartwig JF (2012) J Am Chem Soc 134:12422

103. Larsen MA, Hartwig JF (2014) J Am Chem Soc 136:4287

104. Liskey CW, Hartwig JF (2013) J Am Chem Soc 135:3375
105. Li Q, Liskey CW, Hartwig JF (2014) J Am Chem Soc 136:8755

106. Liskey CW, Wei CS, Pahls DR, Hartwig JF (2009) Chem Commun 5603.

107. Ishiyama T, Isou H, Kikuchi T, Miyaura N (2010) Chem Commun 46:159

108. Ghaffari B, Preshlock SM, Plattner DL, Stapls RJ, Maligres PE, Krska SW, Maleczka Smith MR (2014) J Am Chem Soc 136:14345

109. Chotana GA, Vanchura BA, Tse MK, Staples RJ, Maleczka RE, Jr, Smith MR, III. (2009) Chem Commun 5731.

110. Robbins DW, Hartwig JF (2013) Angew Chem Int Ed 52:933

111. Boller TM, Murphy JM, Hapke M, Ishiyama T, Miyaura N, Hartwig JF (2005) J Am Chem Soc 127:14263

Publisher's Note Springer Nature remains neutral with regard to jurisdictional claims in published maps and institutional affiliations. 